Review

\title{
Current pathophysiological concepts and management of pulmonary hypertension
}

\author{
André P. Lourenço, Dulce Fontoura, Tiago Henriques-Coelho, Adelino F. Leite-Moreira* \\ Department of Physiology and Cardiothoracic Surgery, Faculty of Medicine, University of Porto, Porto, Portugal
}

\section{A R T I C L E I N F O}

\section{Article history:}

Received 11 October 2010

Received in revised form 14 February 2011

Accepted 13 May 2011

\section{Keywords:}

Pulmonary hypertension

Pulmonary arterial hypertension

Pathophysiology

Treatment

\begin{abstract}
A B S T R A C T
Pulmonary hypertension (PH), increasingly recognized as a major health burden, remains underdiagnosed due mainly to the unspecific symptoms. Pulmonary arterial hypertension (PAH) has been extensively investigated. Pathophysiological knowledge derives mostly from experimental models. Paradoxically, common non-PAH PH forms remain largely unexplored. Drugs targeting lung vascular tonus became available during the last two decades, notwithstanding the disease progresses in many patients. The aim of this review is to summarize recent advances in epidemiology, pathophysiology and management with particular focus on associated myocardial and systemic compromise and experimental therapeutic possibilities. PAH, currently viewed as a panvasculopathy, is due to a crosstalk between endothelial and smooth muscle cells, inflammatory activation and altered subcellular pathways. Cardiac cachexia and right ventricular compromise are fundamental determinants of $\mathrm{PH}$ prognosis. Combined vasodilator therapy is already mainstay for refractory cases, but drugs directed at these new pathophysiological pathways may constitute a significant advance.
\end{abstract}

(c) 2011 Elsevier Ireland Ltd. All rights reserved.

\section{Introduction}

Pulmonary hypertension ( $\mathrm{PH})$, is defined by mean pulmonary arterial (PA) pressure (mPAP) elevation above $25 \mathrm{~mm} \mathrm{Hg}$ at rest [1]. In most cases, $\mathrm{PH}$ accompanies cardio-respiratory conditions and does not involve the pulmonary vasculature. However, more rarely it may present itself as pulmonary arterial hypertension (PAH), defined additionally by normal left ventricular (LV) filling pressure [2]. PAH is viewed as a vasoproliferative disease with characteristic pathological abnormalities, such as arteriolar plexiform lesions, as found in most of cases. Initial symptoms, mainly fatigue and dyspnea, are usually vague and insidious, thus most cases are diagnosed when cardiac output (CO) is already low [3]. Right ventricular (RV) failure due to $\mathrm{PH}$ is an important cause of death [4] whose complex pathophysiological

Abbreviations: 5-HT, 5-Hydroxytryptamin, serotonin; 5- $\mathrm{HT}_{2 \mathrm{~A}}$, serotonin type 2A receptor; 6MWT, 6-minute walk test; AC, adenylate cyclase; AS, atrial septostomy; BMP, bone

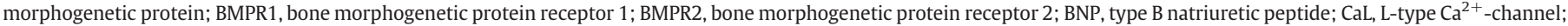

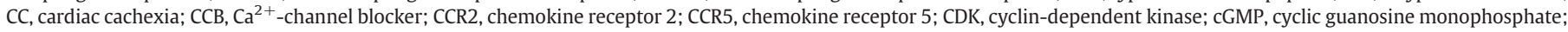

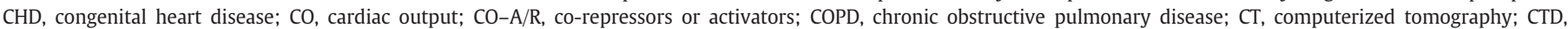

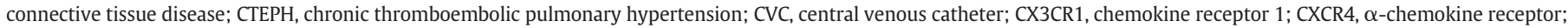

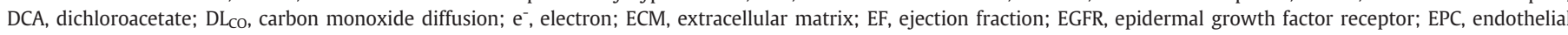

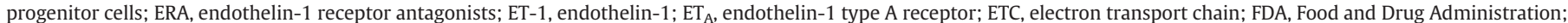

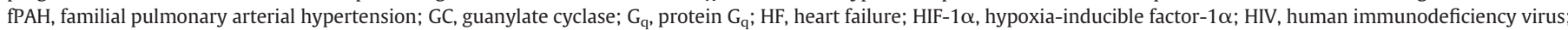

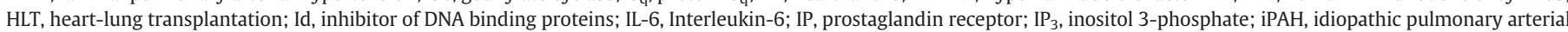

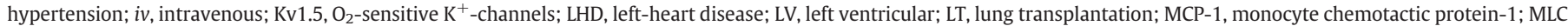

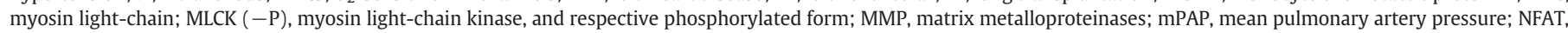

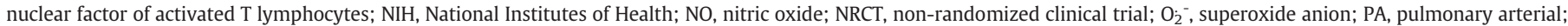

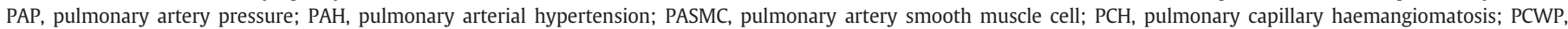

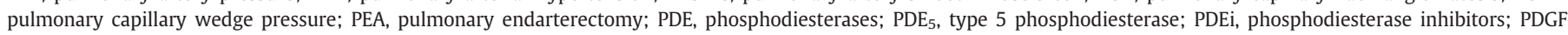

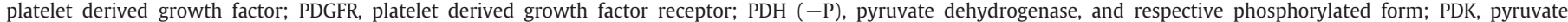

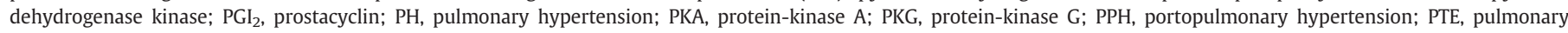

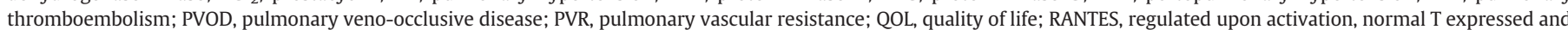

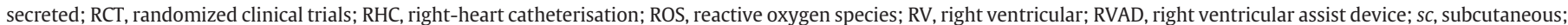

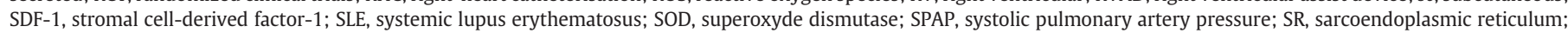

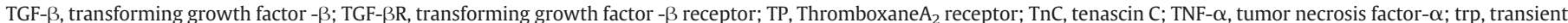

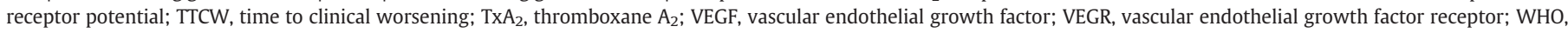
World Health Organization.

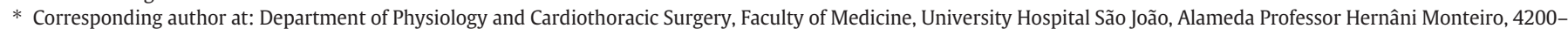
319 Porto, Portugal. Tel.: + 351 225513644; fax: + 351225513646.

E-mail address: amoreira@med.up.pt (A.F. Leite-Moreira). 
Table 1

New classification for pulmonary hypertension (PH) from the 4th World Symposium on PH (Dana Point, 2008).

\begin{tabular}{|c|c|c|}
\hline \multirow{2}{*}{$\begin{array}{l}\text { Pulmonary arterial hypertension } \\
\text { (PAH) }\end{array}$} & \multicolumn{2}{|l|}{ Non-PAH pulmonary hypertension (PH) } \\
\hline & Well defined cause & Unclear or multifactorial \\
\hline$P A H(1)$ & Left-heart disease (2) & Unclear/multifactorial mechanisms (5) \\
\hline Idiopathic & Systolic dysfunction & Haematologic disorders \\
\hline Hereditary & Diastolic dysfunction & Myeloproliferative disorders, etc. \\
\hline Drug/toxin induced & Valvular disease & Systemic disorders \\
\hline Disease associated & Lung diseases/hypoxia (3) & Vasculitis, sarcoidosis, neurofibromatosis, etc. \\
\hline CTD & COPD & Metabolic disorders \\
\hline HIV infection & Interstitial lung disease & Glycogen storage disease, thyroid disorders, etc. \\
\hline Portal hypertension & Sleep-disordered breathing & Congenital heart disease \\
\hline Systemic-pulmonary shunts & Chronic exposure to high altitude & (Other than systemic-pulmonary shunt) \\
\hline Schistosomiasis & Broncho pulmonary dysplasia & Other \\
\hline Chronic haemolytic anaemia & Developmental abnormalities & Fibrosing mediastinitis, chronic renal failure on dialysis, etc. \\
\hline Subclass of $P A H\left(1^{\prime}\right)$ & CTEPH (4) & \\
\hline PVOD and PCH & & \\
\hline
\end{tabular}

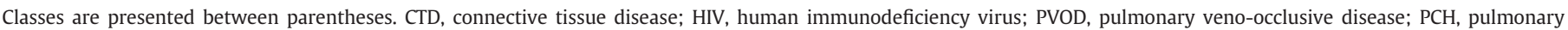
capillary angiomatosis; COPD, chronic obstructive pulmonary disease; CTEPH, chronic thromboembolic PH.

mechanisms are just beginning to be understood. The last decades have been prolific in experimental and clinical studies in both $\mathrm{PAH}$ and PH. Several new drugs have become available [3]. Nevertheless, the prognosis remains poor, and many patients require transplantation [5]. The present review aims to summarize the most recent concepts on the epidemiology, pathophysiology, diagnosis and management of $\mathrm{PH}[6,7]$.

\section{Aetiology and classification}

Several conferences on PH have been fostered by the World Health Organization (WHO). A classification was proposed in 1973 and then modified at Evian in 1988 to better reproduce pathophysiology and clinical presentation. At Venice in 2003, the term primary PH was substituted for idiopathic PAH (iPAH) and pulmonary veno-occlusive disease (PVOD) and pulmonary capillary haemangiomatosis (PCH) were grouped under a single PAH subcategory. In 2008, the 4th World Symposium held in Dana Point (Table 1) endorsed the expression "non-PAH PH" to address categories other than PAH. Additionally, left-heart disease PH was subdivided in systolic heart failure (HF), diastolic HF and valvular heart disease, and schistosomiasis was included as a new class of disease-associated PAH.

\section{Diagnosis}

During the 4th Conference (Table 2) exercise values were excluded as a criteria for diagnosis since the increase in MPAP during exercise frequently exceeds $30 \mathrm{~mm} \mathrm{Hg}$ among the elderly [8]. Additionally, non-invasive echocardiographic criteria of systolic tricuspid regurgitant velocity were contemplated [9]. Nevertheless, transpulmonary flow and pulmonary venous pressure are not reliably measured by echocardiography thus right-heart catheterisation (RHC) remains the gold standard while echocardiography is usually a screening exam. RHC is mandatory in every patient, allowing the selection of patients that may benefit from $\mathrm{Ca}^{2+}$-channel blockers (CCB), the positive responders during vasoreactivity test, those in whom mPAP drops more than $10 \mathrm{~mm} \mathrm{Hg}$ or to values bellow $40 \mathrm{~mm} \mathrm{Hg}$ with normal or

Table 2

New diagnostic criteria for pulmonary hypertension $(\mathrm{PH})$ from the 4 th World Symposium on PH (Dana Point, 2008).

\begin{tabular}{llll}
\hline Method & Normal & Borderline & Clear \\
\hline mPAP $(\mathrm{mm} \mathrm{Hg})$ & $<21$ & $21-25$ & $>25$ \\
systolic tricuspid regurgitation $\left({\left.\mathrm{m} . \mathrm{s}^{-1}\right)}^{-12.5}\right.$ & $<2.5-2.8$ & $>2.8$ \\
\hline
\end{tabular}

mPAP, mean pulmonary artery pressure. increased $\mathrm{CO}$, after administration of a short-acting vasodilator, such as nitric oxide (NO) [10], epoprostenol or adenosine [7].

\section{Epidemiology}

The incidence and prevalence of PAH were estimated to be 2.47.6 cases/million/year and 15-26 cases/million, respectively, in large population studies $[11,12]$. Worldwide prevalence is hard to appraise, but it is surely underdiagnosed [13] and its onus is likely greater than recognized, given the newly revealed associations with haemodialysis [14], the metabolic syndrome [15], and developing world diseases, such as human immunodeficiency virus (HIV) infection, schistosomiasis, and sickle cell disease [16]. Apart from iPAH no precise estimates of incidence or prevalence are available. Nevertheless, non-PAH PH is increasingly recognized as a major health burden. HF is the most common cause of pulmonary hypertension (PH). Not only up to $60 \%$ of patients with severe LV systolic dysfunction but also $70 \%$ of those with HF and normal ejection fraction (EF) [17] develop PH [18,19]. Moreover, $\mathrm{PH}$ afflicts 70\% of patients with rheumatic heart disease [20]. Many patients develop chronic thromboembolic $\mathrm{PH}$ (CTEPH) after pulmonary thromboembolism (PTE) [20] or PH during the progression of chronic obstructive pulmonary disease (COPD). Prevalence ranges from 35 to $90 \%$ according to stage $[21,22]$. Systolic PAP (SPAP) is mostly limited to values ranging from 25 to $35 \mathrm{~mm} \mathrm{Hg}$, and severe $\mathrm{PH}$ is uncommon in advanced COPD [23]. Nevertheless, some patients develop disproportionate PH. These warrant particular attention [21], but even modest PH has a strong impact on quality of life (QOL) and survival [22]. Right HF, its most severe complication, is responsible for $10-30 \%$ of admissions due to decompensated HF [24]. Presently COPD is already responsible for $84 \%$ of cor pulmonale cases and, due to smoking, will be the 3 rd cause of death by 2020 [23]. Portopulmonary hypertension (PPH) is a pulmonary-hepatic vascular disorder that afflicts approximately 5-6\% of patients referred for liver transplantation due to advanced liver disease. It is an underrecognized complication that adversely affects survival, after liver transplantation but presumably also in the early stages of liver disease [32,33].

\section{Clinical presentation and workup}

Severe disease may present with chest pain, palpitation, oedema, ascites, and syncope [9] but earlier treatment, at reversible stages, is fundamental. Diagnosis is challenging, a delay of 2 to 3 years is common and a high suspicion level is needed [13]. The clinician may find RV hypertrophy on the electrocardiogram and hilar PA prominence on the chest X-ray. Echocardiography, generally undertaken after a suspicion, may show increased SPAP, estimated by the velocity of tricuspid 
regurgitation jet, and/or increased RV outflow tract acceleration time. It is fundamental to evaluate valve or primary myocardial disease, as well as the degree of RV hypertrophy and dysfunction [9]. Comprehensive echocardiographic evaluations of RV function have been proposed as useful approaches to risk stratification in PAH [25], although magnetic resonance imaging techniques have also been used [26]. Regarding differential diagnosis, patients with suspicion of PTE should undergo the highly sensitive ventilation-perfusion (V-Q) scan. Staging and operability also relies on chest computerized tomography (CT) and angiography. High-resolution CT is useful to assess PVOD or PCH and to diagnose interstitial lung or connective tissue disease (CTD) [7,9]. Finally antinuclear antibodies, autoimmune disease markers, HIV and viral hepatitis screening, coagulation disorder markers (eg, protein $S$ and C, lupus anticoagulants, von Willebrand factor) and type B natriuretic peptide (BNP) may be carried out for differential diagnosis $[7,9]$. The key feature differentiating $\mathrm{PH}$ resulting from left-heart disease (LHD) is elevated pulmonary capillary wedge pressure (PCWP), which is absent in PAH [27]. To establish the diagnosis of PPH patients must present with portal hypertension and not only haemodynamic criteria for $\mathrm{PH}$, in the absence of other causes, but also increased pulmonary vascular resistance (PVR) [28]. Functional respiratory evaluation relies on spirometry and carbon monoxide diffusion $\left(\mathrm{DL}_{\mathrm{CO}}\right)$. Spirometry may be markedly altered in lung disease, whereas minor changes are found in $\mathrm{PAH}$. $\mathrm{DL}_{\mathrm{CO}}$ impairment correlates with lung vascular surface area and PAH severity [29]. The 6-minute walk test (6MWT), a common clinical trial end-point that evaluates moderate to severe heart or lung disease, is an easily performable and reproducible test originally developed as a surrogate of peak $\mathrm{O}_{2}$ consumption (Table 3). It correlates well with $\mathrm{CO}$, PVR, $\mathrm{O}_{2}$ consumption, QOL, and predicts mortality in PAH [30].

Table 3

The 6-minute walk test (6MWT) in pulmonary hypertension (PH).

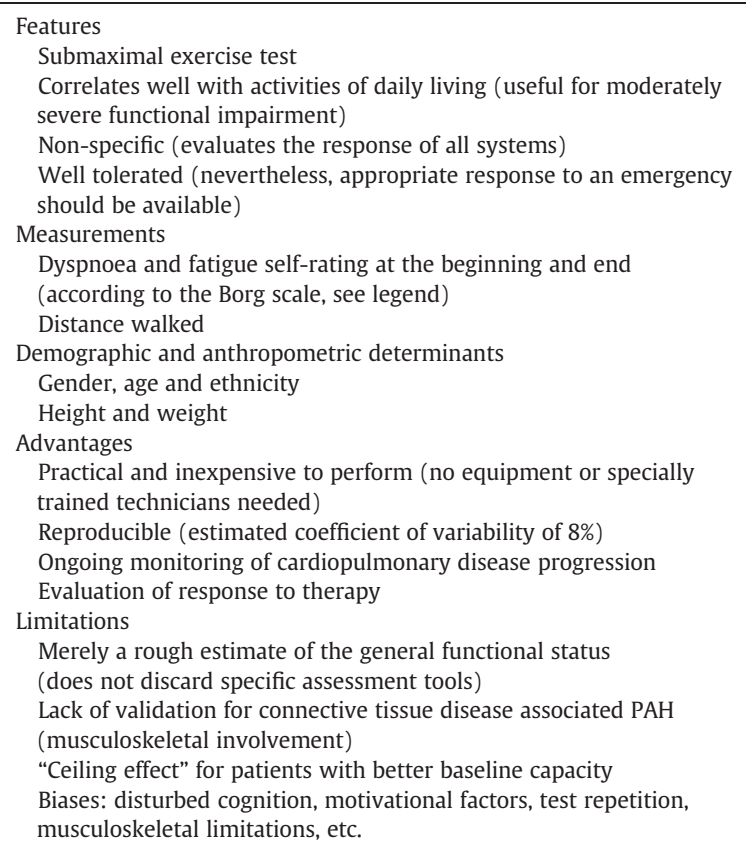

A comprehensive perspective on the 6MWT including indications, contraindications, safety precautions, technical aspects, biases, can be found in the guidelines from the American Thoracic Society [134]. The 6MWT measures the distance that a patient can walk on a flat surface in a period of $6 \mathrm{~min}$, patients are allowed to stop and rest. The normal walked distance for healthy 60 year-old men and women of average constitution is approximately 630 and $550 \mathrm{~m}$, respectively [135], whereas idiopathic $\mathrm{PAH}$ patients on World Health Organization functional class IV usually walk less than $200 \mathrm{~m}$ [30]. A clinically important improvement in walking distance for the PAH patient is generally $44-76 \mathrm{~m}$ [103].

Borg scale: (0) nothing at all, (0.5) just noticeable, (1) very slight, (2) slight, (3) moderate, (4) somewhat severe, (5) severe, (7) very severe, and, finally, (10) maximal [136].
Nevertheless, since it depends on many individual variables, it is not a reliable marker of disease progression [7]. Additionally, its validity has been questioned for CTD [31]. Cardiopulmonary exercise testing, regarded by most as gold-standard in exercise capacity evaluation and still a cornerstone in PAH functional evaluation, also assesses $\mathrm{PH}$ prognosis [32], but requires an experienced laboratory [33,34].

\section{Pathophysiology}

Although no animal model completely recapitulates human PAH, combining multiple insults, according to the multiple-hit hypothesis, yielded severe phenotypes that closely mimic it [35]. Pathophysiological knowledge, derived mostly from these animal studies, once viewed $\mathrm{PH}$ as an imbalance between pulmonary vasoconstrictors and vasodilators [36]. While prostacyclin $\left(\mathrm{PGI}_{2}\right)$ and $\mathrm{NO}$ normally govern vascular tone, endothelin-1 (ET-1), thromboxane $\mathrm{A}_{2}\left(\mathrm{TxA}_{2}\right)$ and serotonin (5-HT) take over in $\mathrm{PH}$. Not surprisingly, lung arteries vasodilators have been the mainstay of therapy (Fig. 1) [3]. Nevertheless, recent research showed this view to be highly incomplete.

\subsection{PAH as panvasculopathy}

PAH is currently viewed as a panvasculopathy, accompanied by histological features as intimal hyperplasia, medial hypertrophy, and arteriolar occlusion by thrombosis, infiltration by inflammatory cells or angioproliferative plexiform lesions (Fig. 1) [7]. Apoptosis may generate apoptosis-resistant endothelial cell phenotypes that cross-talk with PA smooth muscle cell (PASMC) through growth factors such as transforming growth factor- $\beta$ (TGF- $\beta$ ), that are involved in endothelial cell and fibroblast transdifferentiation and PASMC proliferation [37]. Metalloproteinase activation leads to the disruption of the basement membrane enabling inflammatory cell recruitment and further generation of mitogenic peptides [38]. The main mechanisms involved in inflammation, endothelial progenitor cell (EPC) recruitment, growth factor activity and extracellular matrix remodeling are summarized in Fig. 1. PAH shares a mitochondrial-metabolic abnormality with cancer, the "Warburg phenotype", a shift from oxidative phosphorylation to glycolysis (despite adequate $\mathrm{O}_{2}$ supply) that enhances proliferation and prevents apoptosis (Fig. 2). Hyperpolarization of the mitochondrial membrane, reduced production of reactive oxygen species (ROS), normoxic-activation of hypoxia inducible factor- $1 \alpha$, overexpression of pyruvate dehydrogenase kinase (PDK) and decreased expression of $\mathrm{O}_{2}-$ sensitive $\mathrm{K}^{+}$channels (Kv1.5) have been postulated to underlie changes in mitochondrial $\mathrm{O}_{2}$ sensing [39]. PDK activation suppresses aerobic glucose metabolism and decreased Kv1.5 conductance depolarizes the membrane. Dichloroacetate (DCA), a mitochondrial PDK inhibitor and Kv1.5 channel opener, improved $\mathrm{PAH}$ [39] both by activating pyruvate dehydrogenase (PDH) and aerobic metabolism and by restoring membrane potential and ROS production [40].

\subsection{Genetics of $P A H$}

Mutations in bone morphogenetic protein (BMP) receptor-2 (BMPR2), a constitutively active receptor responsive to TGF- $\beta$ superfamily (including BMP), are seen in more than $80 \%$ of familial $\mathrm{PAH}$ (fPAH) cases, leading to loss of smad signalling (Fig. 3) and therefore to increased proliferation and decreased differentiation of PASMC [41,42]. Still, penetrance is low and the mutation is seen only in 10 to $20 \%$ of nonfPAH [43]. Other genetic mechanisms predispose to PAH, namely singlenucleotide polymorphisms of Kv1.5 [18], transient receptor potential (trp) channels [13], and serotonin transporters [44]. Trp channels regulate contractility and cell proliferation by intracellular $\mathrm{Ca}^{2+}[45]$. Elevated 5-HT levels and 5-HT transport have been implicated in PAH pathogenesis [44]. 

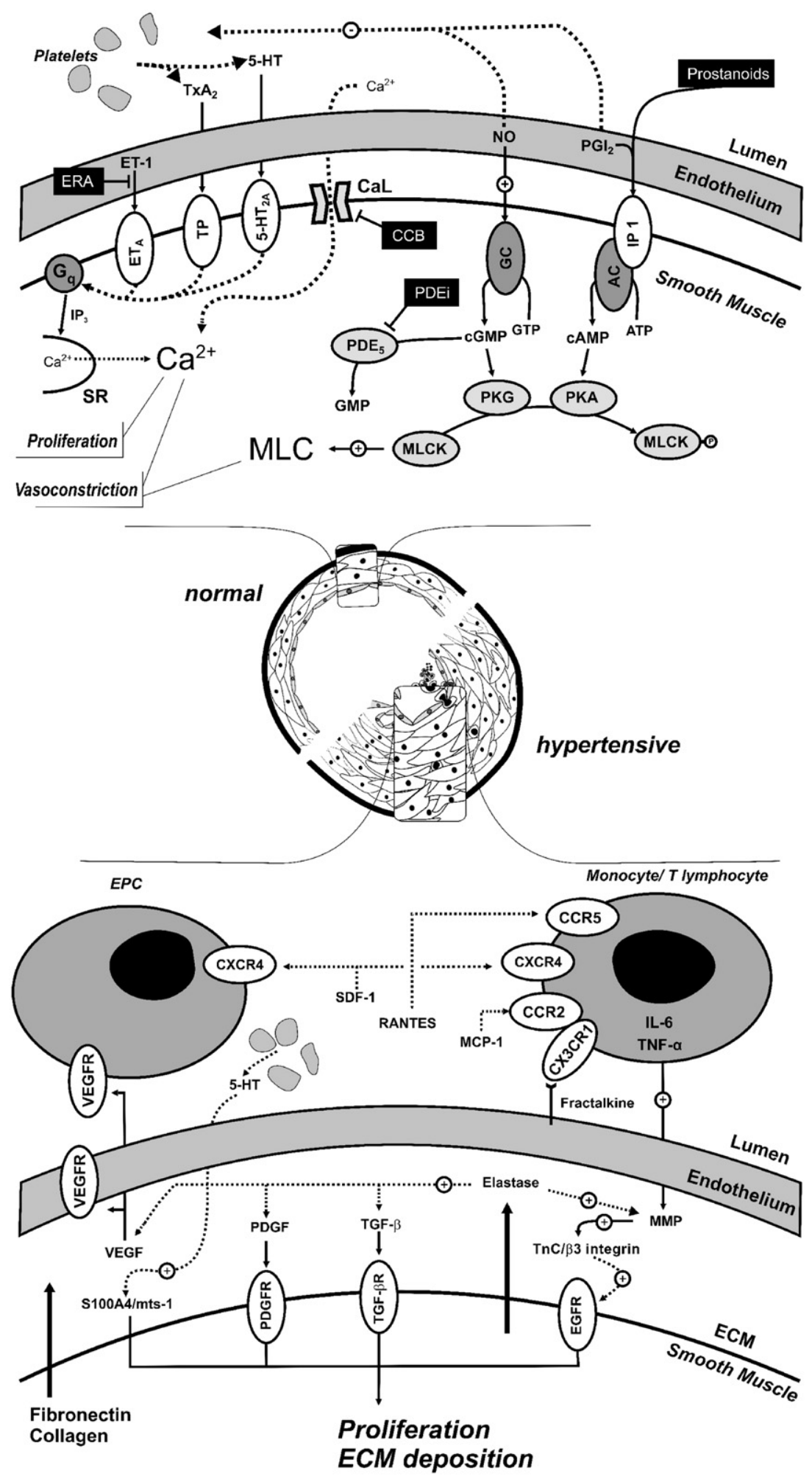

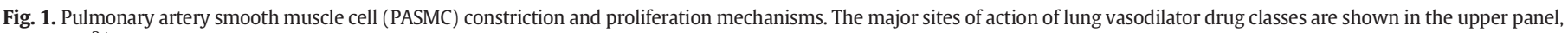
namely $\mathrm{Ca}^{2+}$-channel blockers (CCB), endothelin-1 (ET-1) receptor antagonists (ERA), phosphodiesterase inhibitors (PDEi) and prostanoids. Myosin light-chain (MLC) kinase (MLCK) is inactivated upon phosphorylation (MLCK-P). Other mechanisms are presented in the lower panel. Several cytokines, beyond interleukin- 6 (IL-6) and tumor necrosis factor- $\alpha$ (TNF- $\alpha$ ), mostly produced by fibroblasts, such as stromal cell-derived factor-1 (SDF-1), monocyte chemotactic protein-1 (MCP-1), fractalkine, RANTES (regulated upon activation, normal T expressed and secreted), and vascular endothelial growth factor (VEGF) are upregulated and induce PASMC proliferation and monocyte recruitment, while monocytes upregulate the $\alpha$-chemokine receptor (CXCR4) and chemokine receptors 1, 2 and 5 (CX3CR1, CCR2 and CCR5, respectively) [46]. Elastase, early activated in PH, triggers growth factors release from the extracellular matrix (ECM) and induces tenascin C (TnC) through the activation of matrix metalloproteinases (MMP). When TnC binds surface integrins on PASMCs cell-survival signals are generated and growth factor receptors are further activated. Serotonin (5-HT) induces proliferation of PASMCs by stimulation of S100A4/Mts1, a S100 $\mathrm{Ca}^{2+}$-binding protein family member with metastasis-inducing ability [3]. Endothelial progenitor cells (EPC) may participate in vessel repair, but on the other hand also take part in plexiform lesions [146]. Other abbreviations: $\mathrm{TxA}_{2}$, thromboxane $\mathrm{A}_{2}$; $\mathrm{G}_{\mathrm{a}}$, protein $\mathrm{G}_{\mathrm{q}}$; IP, inositol 3-phosphate; $\mathrm{SR}$, sarcoendoplasmic reticulum; $\mathrm{ET}_{\mathrm{A}}$, ET-1 type A receptor; TP, TxA $\mathrm{A}_{2}$ receptor; 5-HT $2 \mathrm{~A}$, 5-HT type 2A receptor; CaL, Type L $\mathrm{Ca}^{2+}$-channel; GC, guanylate cyclase; AC, adenylate cyclase; IP, prostacyclin receptor; PDE 5 , phosphodiesterase type 5; PKG, protein-kinase G; PKA, protein-kinase A; VEGFR, VEGF receptor; PDGF, platelet derived growth factor; TGF- $\beta$, transforming growth factor- $\beta$; PDGFR, PDGF receptor; TGF $\beta R$, TGF- $\beta$ receptor; EGFR, epidermal growth factor receptor. 


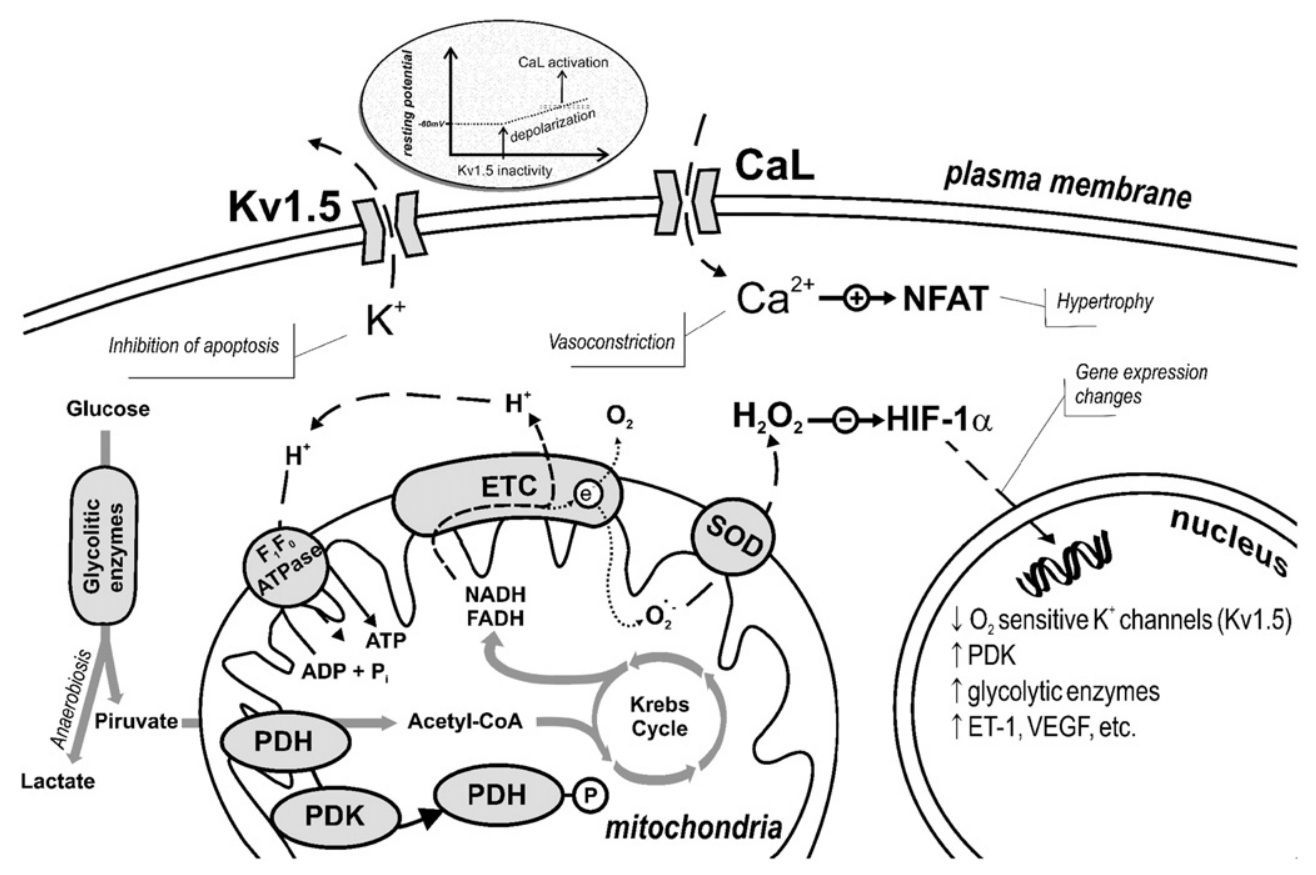

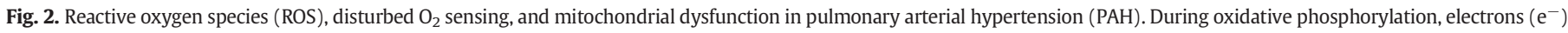

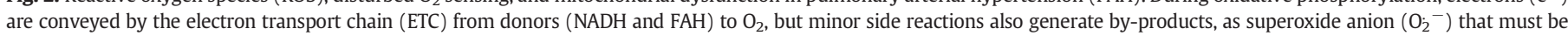

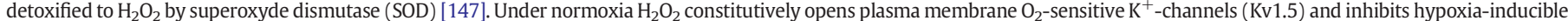

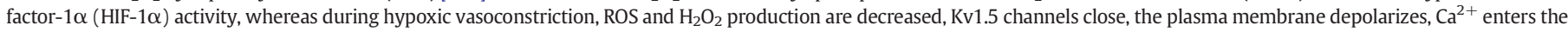

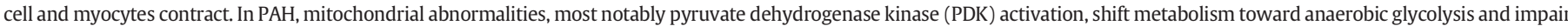

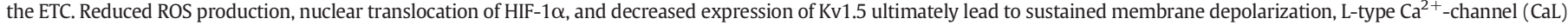

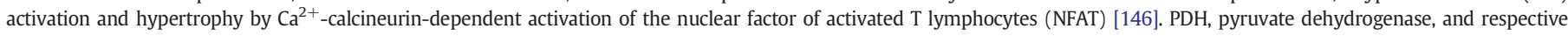
phosphorylated form (-P); ET-1, endothelin-1; VEGF, vascular endothelial growth factor.

\subsection{Inflammation}

The inflammatory state of the vessel wall has recently gained interest as primary event, rather than mere consequence of the disease [46]. Autoantibodies and infiltration by inflammatory cells are common in PAH associated with CTD but are also seen in iPAH [46]. Increased levels of cytokines and their receptors have been demonstrated, particularly in iPAH patients [47], who also present heightened expression of inflammatory cell-associated nuclear factor of activated T lymphocytes (NFAT) [48]. Cytokines involved in the pathogenesis of chronic inflammatory diseases and cancer, such as tumor necrosis factor- $\alpha$ (TNF- $\alpha$ ) and IL-6, may play a role in PAH vasculopathy [49]. Our group has tested an anti-inflammatory approach in experimental models of PH with variable success [50,51]. Inflammatory activation may also underlie systemic manifestations, for instance cardiac cachexia (CC). CC is characterized not only by neuroendocrine and inflammatory activation but also by suppressed appetite and nutritional derangements [52] and poses a significant prognostic burden on HF patients [53]. CC accompanies the progression of $\mathrm{PH}$, indeed, patients with severe $\mathrm{PH}$ have exaggerated and early post-prandial satiety hormone response [54].

\subsection{The $\mathrm{RV}$ in $\mathrm{PH}$}

The RV effectively serves as a thin, compliant reservoir for blood returning to the LV whose primary function of is to deliver deoxygenated blood to the lungs, while maintaining low-pressure perfusion [55]. It is thus best suited for volume work and unable to suddenly withstand high PAP. Sudden afterload decreases stroke volume and dilates the RV [56], whereas progressive overload allows gradual hypertrophy, remodeling and substantial increases in mPAP. Curiously, although RV response partly determines the outcome [26,57], despite the fact that the RV was shown to be an independent therapeutic target in experimental PH [58], and even though RV remodeling is potentially reversible, as seen after lung transplantation (LT) [59], little is known about the mechanisms underlying RV dysfunction [55]. Many have shown neuroendocrine activation can contribute to RV hypertrophy [60,61], fibrosis and apoptosis, as well as to oxidative stress, and activation of inflammatory cytokines and growth factors [55,62]. A state of myocardial hibernation has been proposed based on systolic flow impediment to coronary arteries which is proportional to $\mathrm{RV}$ pressure and mass [63]. In contrast to the normal flexible metabolism, in RV hypertrophy the myocardium relies solely on anaerobic glucose metabolism partly due to PDK activation [64] and possibly impaired mitochondrial energy-producing ability [65]. Moreover, changes in cardiomyocyte redox state can underlie electrophysiological instability and remodeling, by mechanisms similar to those already described for pulmonary vessels [66]. Experimental findings and clinical observations suggest that elevated MPAP cannot be the single driver for RV failure [62], therefore, targeting the RV may be a promising approach [6]. As for the LV myocardium, echocardiography shows compromised LV function in various aetiologies of PH [67], mainly due to ventricular interdependence and impaired filling [68]. Nevertheless, myocardial abnormalities partly underlie LV dysfunction. Indeed, despite immediate restoration of LV geometry and RV function, LV filling is only normalized 1 year after single-LT in severe PH [69], and combined heart-lung transplantation (HLT) is favored if LV function is impaired because the LV may not recover after LT alone [70]. We have confirmed intrinsic LV myocardial dysfunction and neuroendocrine activation experimentally [61,71].

\subsection{Pathophysiology of non-PAH PH}

Contrarily to $\mathrm{PAH}$, and paradoxically, few data are available on the pathophysiology of the far more common non-PAH PH. Regarding chronic pulmonary disease, several mechanisms are potentially responsible. Hypoxia, such as is found at high altitude, is known to 


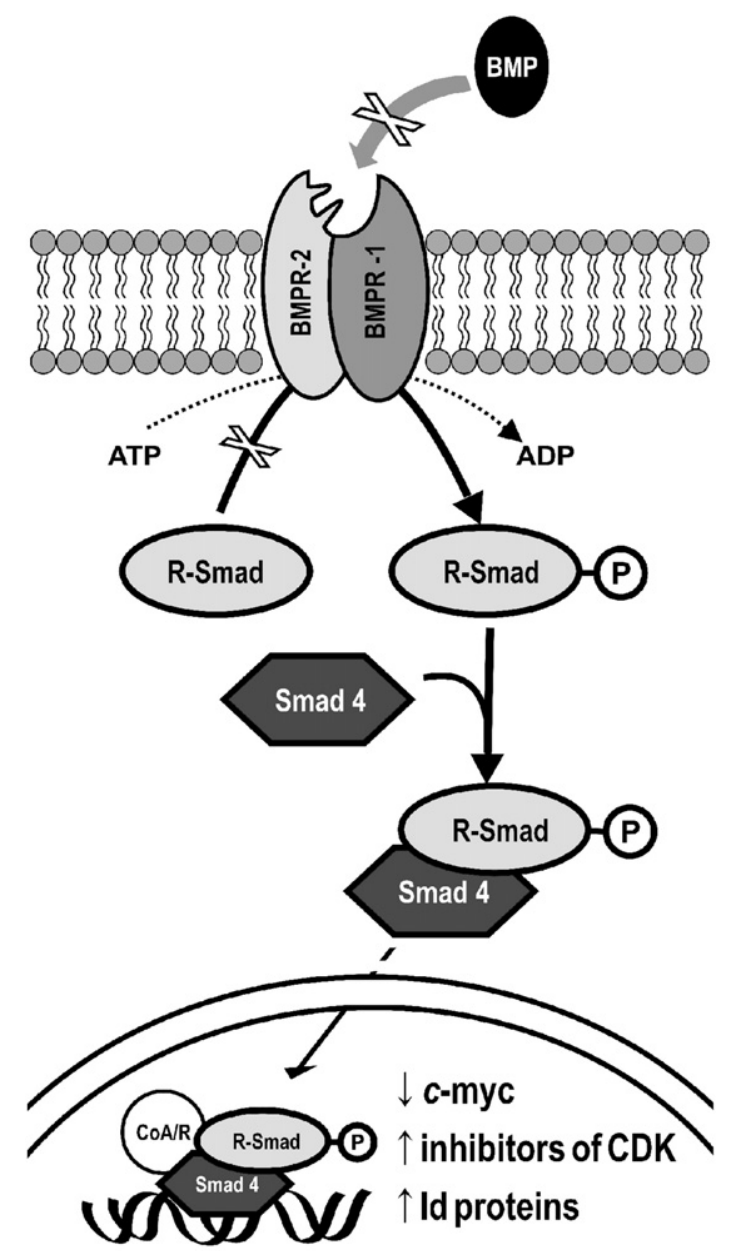

\section{SUPRESSION OF SMAD SIGNALING}

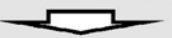

- shift from contractile to synthetic phenotype

- rearrangement of actin filaments

- cytokine activation and inflammatory cell recruitment

- proliferation and apoptosis

- collagen and matrix synthesis

Fig. 3. Growth-promoting pathways in bone morphogenetic protein (BMP) receptor type 2 (BMPR-2) mutations. Bone morphogenetic protein (BMP) receptor type 1 (BMPR-1) and -2 dimerize upon activation by BMP and initiate a cytosolic receptoractivated Smad protein-signaling cascade. Smads (homology with drosophila's mothers against decapentaplegic - MAD - and Caenorhabditis elegans' small phenotype - sma proteins) ultimately complex with common partner Smad4 and translocate to the nucleus. The weak Smad-DNA interaction requires co-repressors or activators $(\mathrm{Co}-\mathrm{A} / \mathrm{R})$ [148]. Signal disrupting mutations in BMPRII can be found in the ligandbinding domain, in the kinase domain or in the cytoplasmic tail. Suppression of Smad signalling partly underlies the hypertrophic and proliferative phenotype of pulmonary artery smooth muscle cells (PASMC) [149]. In normal PASMC, BMP stimulates transcriptional activation of cyclin-dependent kinase (CDK) inhibitors and repression of c-myc. CDK inhibitor prevents progression in cell cycle, while c-myc encodes a transcriptional activator responsible for growth and proliferation [150]. Inhibitor of DNA (Id) binding proteins, a family deprived of DNA-binding domain that acts by inhibition of transcription factors, are also major targets. Failure to induce Id genes makes PASMC unresponsive to the growth suppressive effects of BMPs [151]. Prostanoids, by cyclic adenosine monophosphate and a direct effect on the Id promoter, drive the expression of Id proteins [148].

induce $\mathrm{PH}$, but low arterial $\mathrm{O}_{2}$ is not an independent predictor of mPAP, therefore after the Evian Conference COPD-associated PH was no longer classified as 'associated with hypoxemia' [29]. Pulmonary vessels in COPD consistently develop intimal fibro-elastic thickening and overall muscularisation but this does also not provide a consistent explanation [72]. Endothelial dysfunction and inflammation, are currently viewed as the key to vascular remodeling [73]. Findings strongly suggest an involvement of vasoactive mediators and cytokines [72]. Plasma IL-6 correlates with mPAP and certain IL-6 genotypes are associated with PH development in COPD [74]. Indeed, vascular remodelling and endothelial dysfunction can be observed in mild COPD without hypoxaemia and in ordinary smokers [75]. Symptomatic CTEPH affects $3.8 \%$ of patients within 2 years of initial PTE [76], but up to $5.1 \%$ of patients may develop definite CTEPH [77]. Unlike PAH, CTEPH is mainly associated with obstructions in larger vessels. Its pathophysiology remains obscure, while most argue that it results from recurrent pulmonary embolism, it has also been suggested that endothelial dysfunction could lead to thrombus formation in situ, and, in fact many patients do not have a clear history of embolism [78]. Variable degrees of small vessel disease, a PAH-like vasculopathy, accompany CTEPH and the mechanisms that underlie them are probably common to $\mathrm{PAH}$, namely endothelial dysfunction [79]. As for LHD, two major mechanisms underlie $\mathrm{PH}$, an hydrostatic and a vasoreactive. Increased filling pressures are transmitted to the pulmonary circulation and generate, initially, pulmonary venous hypertension, but, later on, also PVR increase. SPAP correlates tightly and is roughly twice the PCWP [80]. When the compensatory mechanisms of the highly distensible pulmonary vasculature are surpassed PA pressure increases first on exertion and later on also at rest. Endothelial dysfunction, sympatheticadrenergic stimulation and disturbances of 5-HT, TxA $\mathrm{A}_{2}$ and angiotensinII production further aggravate $\mathrm{PH}$ [81], contributing to structural changes at the capillary level, namely swelling of the endothelial cells, thickening of the basal lamina, and proliferation of reticular and elastic fibrils. These changes participate in increasing PVR, decreasing permeability of the vascular bed, and lower the possibility of developing pulmonary edema, but ultimately lead to increased likelihood of right ventricular failure [82]. These changes are initially reversible if cardiac filling pressures are reduced, but on the long term become irreversible and pose a relative contraindication to cardiac transplantation [83].

\subsection{Prognosis}

Although PAH has been most extensively studied, its rarity, diverse etiology and changing therapeutics preclude an estimation of yearly mortality rates. An early registry followed 194 patients with iPAH from 1981 to 1985 and estimated a median survival of 2.8 years, with 1-, 3-, and 5-year survival rates of 68,48 , and $34 \%$, respectively [84]. Presentday registries, however, reveal a better prognosis, with 1 year survival ranging 83 to $88 \%$ and 3 year survival 58 to $72 \%$ [85]. A risk-prediction equation could be derived from multivariate analysis, including gender, 6MWT, and CO at diagnosis as covariates [86]. Four variables were associated with increased 1-year survival: WHO functional class I, $6 \mathrm{MWT} \geq 440 \mathrm{~m}, \mathrm{BNP}<50 \mathrm{pg} / \mathrm{mL}$, and $\mathrm{DL}_{\mathrm{CO}} \geq 80 \%$ of predicted [86]. Recently, echocardiographic evaluation of RV function has also been successfully used for risk stratification in PAH [25]. The progression in non-PAH PH is generally slower and the overall prognosis is better. Still, there is a substantial impact on QOL and survival [22,27]. The level of PAP is a good indicator of prognosis in COPD and a 50\% 5-year survival rate has been reported with $\mathrm{PH}$ [87]. Regarding CTEPH, survival changed dramatically. Before the advent of pulmonary endarterectomy (PEA) patients who had mPAP higher than $30 \mathrm{~mm} \mathrm{Hg}$ steadily progressed to $\mathrm{PH}$ and 2 year-survival was lower than $20 \%$ after it reached $50 \mathrm{~mm} \mathrm{Hg}$ [88]. Currently, in experienced centres and carefully selected patients, PEA provides remarkable haemodynamic and clinical improvement with low procedural mortality rate [5]. In severe HF, the EF of the RV is the most important determinant of short-term prognosis among hemodynamic variables [89]. Although increased mPAP is frequently coupled with reduced RV function, exceptions must be taken in account during prognostic stratification [19]. 
Table 4

Summary of randomized clinical trials (RCT) on pulmonary arterial hypertension (PAH)

\begin{tabular}{|c|c|c|c|c|c|c|c|c|}
\hline Class & Drug & Year & Author & Study type & Sample & Patients & Follow-up & Positive outcomes \\
\hline \multirow[t]{5}{*}{ Prostanoid } & Epoprostenol & 1996 & Barst [96] & RCT (not blind) & iPAH (WHO III-IV) & 81 & 12 weeks & $\begin{array}{l}\text { Haemodynamics, QOL, } \\
\text { WHO class, survival }\end{array}$ \\
\hline & Treprostinil (sc) & 2002 & Simmoneau [98] & $\mathrm{RCT}$ & $\begin{array}{l}\text { iPAH, CTD and CHD } \\
\text { (WHO II-IV) }\end{array}$ & 470 & 12 weeks & $\begin{array}{l}\text { Haemodynamics, 6MWT, } \\
\text { clinical evaluation }\end{array}$ \\
\hline & Iloprost (inh) & 2002 & $\begin{array}{l}\text { Olschewski [99] } \\
\text { (AIR) }\end{array}$ & RCT & $\begin{array}{l}\text { iPAH, CTD and CTEPH } \\
\text { (WHO III-IV) }\end{array}$ & 203 & 12 weeks & $\begin{array}{l}\text { Haemodynamics, 6MWT, } \\
\text { QOL, WHO class }\end{array}$ \\
\hline & Beraprost & 2002 & $\begin{array}{l}\text { Galiè [137] } \\
\text { (ALPHABET) }\end{array}$ & $\mathrm{RCT}$ & $\begin{array}{l}\text { iPAH, CTD, CHD, portal } \\
\text { hypertension } \\
\text { and HIV (WHO II-III) }\end{array}$ & 130 & 12 weeks & $\begin{array}{l}\text { Exercise tolerance, 6MWT, } \\
\text { clinical evaluation }\end{array}$ \\
\hline & & 2003 & Barst [138] & $\mathrm{RCT}$ & $\begin{array}{l}\text { iPAH, CTD and CHD } \\
\text { (WHO II-III) }\end{array}$ & 116 & 1 year & $\begin{array}{l}\text { Exercise tolerance, } 6 \text { MWT, } \\
\text { TTCW, }\end{array}$ \\
\hline \multirow[t]{10}{*}{ ERA } & Bosentan & 2002 & $\begin{array}{l}\text { Rubin [103] } \\
\text { (BREATHE1) }\end{array}$ & $\mathrm{RCT}$ & $\begin{array}{l}\text { iPAH, CTD or SLE } \\
\text { (WHO III-IV) }\end{array}$ & 213 & 16-28 weeks & $\begin{array}{l}\text { Exercise tolerance, 6MWT, } \\
\text { WHO class, TTCW; }\end{array}$ \\
\hline & & 2005 & McLaughlin [139] & RCT (not blind) & iPAH (WHO III-IV) & 169 & 3 years & Survival (NIH prediction) \\
\hline & & 2006 & $\begin{array}{l}\text { Galiè [140] } \\
\text { (BREATHE5) }\end{array}$ & $\mathrm{RCT}$ & CHD (WHO III) & 54 & 16 weeks & Haemodynamics, 6 MWT \\
\hline & & 2008 & $\begin{array}{l}\text { Galiè [106] } \\
\text { (EARLY) }\end{array}$ & $\mathrm{RCT}$ & $\begin{array}{l}\text { iPAH, CTD, CHD, HIV } \\
\text { (WHO II) }\end{array}$ & 185 & 6 months & $\begin{array}{l}\text { Haemodynamics, } \\
\text { NT-pro-BNP and TTCW }\end{array}$ \\
\hline & & 2008 & $\begin{array}{l}\text { Jais [123] } \\
\text { (BENEFIT) }\end{array}$ & $\mathrm{RCT}$ & CTEPH (WHO II-IV) & 157 & 16 weeks & Haemodynamics \\
\hline & Ambrisentan & 2005 & Galiè [141] & $\mathrm{RCT}$ (dose ranging) & $\begin{array}{l}\text { iPAH, CTD, HIV and } \\
\text { anorexigen } \\
\text { (WHO II-III) }\end{array}$ & 64 & $\begin{array}{l}12+12 \text { weeks } \\
\text { (not-blind) }\end{array}$ & $\begin{array}{l}\text { Haemodynamics, } 6 \text { MWT, } \\
\text { clinical evaluation }\end{array}$ \\
\hline & & 2008 & $\begin{array}{l}\text { Galiè [142] } \\
\text { (ARIES } 1 \text { and 2) }\end{array}$ & $\mathrm{RCT}$ & $\begin{array}{l}\mathrm{iPAH}, \mathrm{CTD}, \mathrm{HIV} \text { and } \\
\text { anorexigen }\end{array}$ & $\begin{array}{l}202+192 \\
\text { (parts } 1 \text { and } 2)\end{array}$ & 12 weeks & $\begin{array}{l}\text { 6MWT, WHO class, QOL, } \\
\text { TTCW, NT-pro-BNP }\end{array}$ \\
\hline & & 2009 & $\begin{array}{l}\text { Oudiz [108] } \\
\text { (ARIES } 1,2 \text { and E) }\end{array}$ & $\mathrm{RCT}$ & $\begin{array}{l}\text { iPAH, CTD, HIV and } \\
\text { anorexigen }\end{array}$ & 383 & 2 years & $\begin{array}{l}\text { 6MWT, TTCW and survival } \\
\text { (combined outcome) }\end{array}$ \\
\hline & Sitaxsentan & 2004 & $\begin{array}{l}\text { Barst [143] } \\
\text { (STRIDE1) }\end{array}$ & RCT & $\begin{array}{l}\text { iPAH, CTD and CHD } \\
\text { (WHO II-IV) }\end{array}$ & 178 & 12 weeks & $\begin{array}{l}\text { Haemodynamics, 6MWT, } \\
\text { WHO class }\end{array}$ \\
\hline & & 2006 & $\begin{array}{l}\text { Barst [144] } \\
\text { (STRIDE2) }\end{array}$ & $\mathrm{RCT}$ & $\begin{array}{l}\text { iPAH, CTD and CHD } \\
\text { (WHO II-IV) }\end{array}$ & 245 & 18 weeks & 6MWT, WHO class \\
\hline \multirow[t]{2}{*}{ PDEi } & Sildenafil & 2005 & $\begin{array}{l}\text { Galiè [110] } \\
\text { (SUPER1) }\end{array}$ & $\mathrm{RCT}$ & $\begin{array}{l}\text { iPAH, CTD and CHD } \\
\text { (WHO II-IV) }\end{array}$ & 278 & 12 weeks & $\begin{array}{l}\text { Haemodynamics, 6MWT, } \\
\text { WHO class }\end{array}$ \\
\hline & Tadalafil & 2009 & $\begin{array}{l}\text { Gàlie [145] } \\
\text { (PHIRST) }\end{array}$ & $\mathrm{RCT}$ (dose ranging) & $\begin{array}{l}\text { iPAH, CTD, CHD, HIV and } \\
\text { anorexigen }\end{array}$ & 405 & 16 weeks & $\begin{array}{l}\text { Haemodynamics, WHO } \\
\text { class, 6MWT, TTCW, QOL }\end{array}$ \\
\hline \multirow[t]{3}{*}{ Combined } & Bosentan + Iloprost (inh) & 2006 & $\begin{array}{l}\text { McLaughlin [114] } \\
\text { (STEP) }\end{array}$ & $\mathrm{RCT}$ & iPAH, APAH (WHO III) & 67 & 12 weeks & $\begin{array}{l}\text { Haemodynamics, WHO } \\
\text { class, TTCW }\end{array}$ \\
\hline & $\begin{array}{l}\text { Epoprostenol }+ \\
\text { sildenafil }\end{array}$ & 2008 & $\begin{array}{l}\text { Simmoneau } \\
\text { [115] (PACES) }\end{array}$ & $\mathrm{RCT}$ & iPAH and CTD & 267 & 16 weeks & $\begin{array}{l}\text { Haemodynamics, exercise } \\
\text { tolerance, QOL, TTCW }\end{array}$ \\
\hline & $\begin{array}{l}\text { Bosentan or sildenafil + } \\
\text { treprostinil (inh) }\end{array}$ & 2010 & $\begin{array}{l}\text { McLaughlin [100] } \\
\text { (TRIUMPH I) }\end{array}$ & $\mathrm{RCT}$ & $\begin{array}{l}\text { iPAH, CTD, HIV and } \\
\text { anorexigen (WHO III-IV) }\end{array}$ & 255 & 12 weeks & QOL, NT-pro-BNP \\
\hline
\end{tabular}

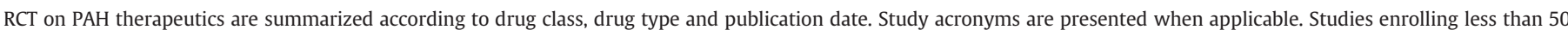

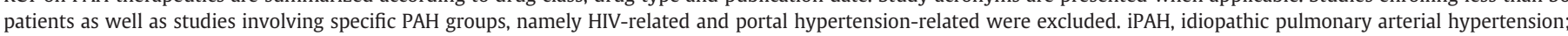

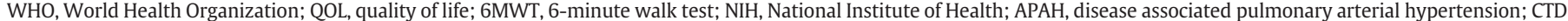

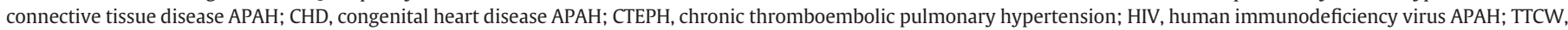

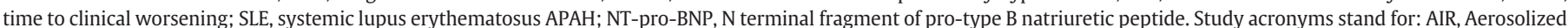

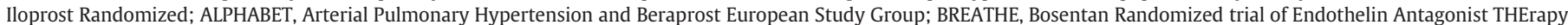

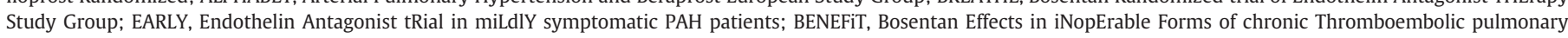

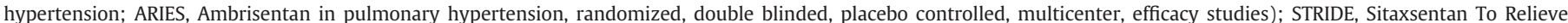

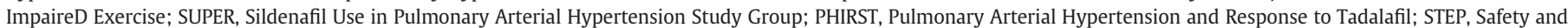

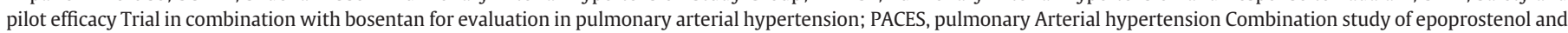
sildenafil; TRIUMPH I, efficacy and tolerability of inhaled Treprostinil sodium in patients with severe pulmonary arterial hypertension.

\section{Therapeutics}

Treatment of PAH has evolved considerably over the past decade, many treatment algorithms have been proposed, mainly based on studies conducted in patients with iPAH and PAH associated with CTDs. In Table 4 we summarize the major therapeutic studies on PAH.

Several general measures can be recommended. Regarding exercise practice, patients may practice low level aerobic exercise, such as walking, whereas exertion that may lead to breathlessness, dizziness or chest pain should be avoided. Some patients may not tolerate high altitudes, for instance during airplane flights, and therefore require in-flight $\mathrm{O}_{2}$ administration. It is currently recommended for patients either in WHO classes III and IV or whose arterial $\mathrm{O}_{2}$ pressure is below $60 \mathrm{~mm} \mathrm{Hg}$. Dietary sodium restriction can be advised particularly in RV failure $\left(\leq 2.4{\mathrm{~g} . \mathrm{d}^{-1}}^{-}\right)$, but current European
Society of Cardiology guidelines do not recommend it. Immunization against common respiratory pathogens is recommended [7]. PAH is a contraindication to pregnancy due to the high mortality rate [90].

Despite the lack of randomized controlled trials (RCT), the initial therapeutic, and largely supportive, approaches to the treatment of $\mathrm{PAH}$ were anticoagulation, diuretics, $\mathrm{O}_{2}$ therapy and digoxin. Observational studies suggested improved survival after anticoagulation in patients with $\mathrm{iPAH}$, therefore most experts recommend anticoagulation in $\mathrm{PAH}$, heritable $\mathrm{PAH}$, and $\mathrm{PAH}$ due to use of anorexigens (titrated to international normalized ratio of 2.0-3.0). As for non-iPAH, anticoagulation may be advised for severe cases [7]. Diuretics are used to manage $\mathrm{HF}$ symptoms. $\mathrm{O}_{2}$ therapy in hypoxemia is employed strictly to avoid vasoconstriction. Based on a short-term effect study, digoxin may be used in patients with low $\mathrm{CO}$, but its use is clearly only recommended in patients with supraventricular tachyarrhythmias 
[91]. During the last two decades substantial RCT and pharmacological research have yielded several new and more effective alternatives to treat $\mathrm{PH}$. The main pharmacological classes will be briefly presented. Most of the studies are small scaled and short-termed, not suitable for survival analysis, but a recent meta-analysis found an overall benefit in mortality [92]. Nevertheless, most therapies reduce mPAP by only 10$20 \%$, with the exception of strong responders to CCB. Despite all the advancement, many patients still remain symptomatic, with a suboptimal QOL and warrant combined therapy or even invasive or surgical procedures.

\section{1. $\mathrm{Ca}^{2+}$ channel blockers}

A marked improvement in survival rates was shown with long-term high-dose CCB therapy for patients with iPAH and a positive vasoreactivity test [93]. Long acting nifedipine, diltiazem, or amlodipine are more commonly used. If there is no recovery to functional classes I or II patients are deemed as non-responders and should discontinue CCB. True responders are rare in non-iPAH [94]. Indiscriminate use is not recommended, due to systemic vasodilation and negative inotropic effects [95].

\subsection{Prostanoids}

There are presently several commercially available prostanoid formulations. Intravenous (iv) epoprostenol was the first shown to improve functional class, hemodynamics and survival in a 12-week follow-up period in patients with iPAH of classes III and IV [96]. These beneficial effects were reproduced in long-term observational comparisons with historical controls [97]. Moreover, epoprostenol was also evaluated in CTD associated PAH and other forms of non IPAH with favourable outcomes. Presently, because of the complex administration and cumbersome follow-up, epoprostenol use is mainly confined to highly experienced centres. Patients must keep a central venous catheter (CVC) and handle drug preparation and infusion. Dosing must be carefully titrated. Most patients do well with an initial in-hospital dose of $2 \mathrm{ng} \cdot \mathrm{kg}^{-1} \cdot \mathrm{min}^{-1}$ and a dose range between 25 and $40 \mathrm{ng} \cdot \mathrm{kg}^{-1} \cdot \mathrm{min}^{-1}$. Unfortunately, substantial side-effects have been reported, namely flushing, headache, and sudden death after abrupt discontinuation, as well as risk of infection related to CVC [7]. Treprostinil, a longer half-life prostanoid, amenable to administration by subcutaneous $(s c)$ route, circumventing the need for CVC, showed minor beneficial effects in patients with functional classes II-IV of idiopathic, CTD and (CHD) associated PAH [98]. The Food and Drug Administration (FDA) approved it for functional classes II-IV also by $i v$ route, when the $s c$ route is not tolerated due to pain or erythema. It is currently not approved by the European Medicines Agency (EMA). On another attempt to facilitate administration, iloprost was developed for inhalation by aerosol device. After a 12-week administration, iloprost improved the 6MWT and functional class in a multicentre RCT enrolling patients with PAH of different aetiologies [99]. Treprostinil is now also available by inhalation [100], and trials of oral formulations have been iniciated (FREEDOM, Trial of Oral Treprostinil in Pulmonary Arterial Hypertension).

\subsection{Endothelin receptor antagonists}

We have previously reviewed the role of ET-1 and its antagonists (ERA) in cardiovascular pathophysiology [101]. Briefly, after a small magnitude RCT had shown improvement in the 6MWT, MPAP and CO with the non-selective ERA bosentan [102], a larger scale study conducted in patients with idiopathic or CTD associated PAH, reproduced these findings and reported improvement in time to clinical worsening (TTCW), a secondary endpoint defined as a composite of mortality, LT, hospitalization, discontinuation due to lack of recovery or need for epoprostenol or atrial septostomy (AS) [103]. As an important side-effect, bosentan dose-dependently altered hepatic function. Ane- mia can also occur and the FDA therefore recommends liver function test and haematocrit surveillance [7]. Long-term evaluation as a firstline drug in functional class III patients also revealed good results, although many patients demanded prostanoids [104]. In fact, improved survival was only demonstrated by comparison with historical data from epoprostenol treated iPAH WHO class III patients, and unfortunately the two cohorts were not comparable [105]. By now, bosentan has also been tested in CHD, HIV-associated PAH and CTEPH with favourable results. Moreover, it has been successfully used in a large sample of mildly symptomatic, class II, multiple cause-PAH patients improving haemodynamics and TTCW [106]. Sitaxentan a selective $\mathrm{ET}_{\mathrm{A}} \mathrm{ERA}$ initially was shown to have comparable effects to bosentan in $\mathrm{PAH}$ and PAH associated with CTD or CHD, but has been withdrawn from market due to two fatal cases of liver failure [107]. Ambrisentan, another selective $\mathrm{ET}_{\mathrm{A}}$ ERA, also improved the 6MWT and TTCW, which was reproducible in long-term studies [108]. It is approved by the FDA since 2007 and it has also been approved by the EMA for PAH patients in functional classes II and III. Indeed, it is the only ERA approved for WHO class II.

\subsection{Phosphodiesterase inhibitors}

Phosphodiesterases (PDE) degrade cyclic guanosine monophosphate (cGMP) therefore PDE inhibitors (PDEi) potentiate the effects of cGMP generated by NO activation of guanylate cyclase. NO and NO donors have been extensively used as a rescue therapy to mitigate MPAP in the perioperative period and in the critically ill patient, particularly in children [109]. Sildenafil, the first used PDEi, was shown to improve 6MWT, WHO functional class and mPAP in idiopathic, CTD or CHD associated PAH, but there were no differences in TTCW [110]. The FDA approved sildenafil in low doses for patients with PAH although there is some debate as to whether higher doses might confer additional benefits [111]. Other PDEi are currently under study. Tadalafil, recently approved by both FDA and the EMA, has a longer half-life than sildenafil and is amenable to once-daily dosing. Nevertheless, unlike sildenafil, due to its hepatic metabolism and renal clearance, dose adjustments are recommended for patients with renal or hepatic function impairment [112].

\subsection{Combination therapy}

The possibility to combine distinct drug classes that target different molecular pathways in order to improve clinical efficacy and minimize side-effects is an attractive perspective. After an initial attempt to combine bosentan and epoprostenol in a small scale and underpowered trial conducted on patients with either iPAH or PAH associated to CTD that proved unsuccessful [113], another trial that combined inhaled iloprost with bosentan in patients who remained symptomatic showed improvement in functional class, TTCW and haemodynamics [114]. More recently, the addition of sildenafil to PAH patients who remained symptomatic on a stable dose of iv epoprostenol improved the 6MWT, as well as MPAP, CO, and TTCW [115], while the addition of inhaled treprostinil to WHO III and IV PAH patients undergoing either bosentan or sildenafil chronic therapy showed only clinical benefits in QOL [100], and the introduction of oral treprostinil failed to achieve statistical significance in 6MWT (FREEDOM, unpublished results).

\subsection{Invasive and surgical strategies in $P A H$}

These include AS and LT or HLT. Other possibilities, such as the RV mechanical assist devices (RVAD) are still poorly investigated. AS creates a right-to-left shunt that unloads the RV, decreases mPAP, and improves LV filling. The increase in $\mathrm{CO}$ offsets the shunting of deoxygenated blood and ameliorates $\mathrm{O}_{2}$ delivery. Increased $\mathrm{CO}$ allows bridging to transplantation in up to $40 \%$ of patients [116]. Nevertheless, it is merely palliative and procedural mortality is still high therefore it is just a last resort for patients on maximal medical therapy and inotropic support. Improved 
techniques are being currently explored to reduce procedural risk [5]. Currently, PAH is responsible for approximately 4\% of LT and HLT, and although there is a substantial procedural related mortality, the longterm outcome is better than with medical therapy alone, with a $47 \%$ survival after 5 years [117]. The type of transplant is still a matter of debate and highly related to the experience of each centre. Generally HLT is preferred either when patients have intractable HF or are dependent on inotropic support or if PH is secondary to CHD or LHD [70].

\subsection{Therapeutic algorithm}

Management must be tailored to each patient according to disease severity, comorbid conditions, drug side-effects and each centre's experience. CCB are reserved for iPAH patients with a positive vasoreactivity test and stable hemodynamics, otherwise first line therapy should consist of ERA or PDEi, unless the oral route is not available, patients are in functional class IV or present overt RV failure. In these cases, the first choice is an iv prostanoid. Moreover, combination therapy should always be kept in mind, particularly when side-effects arise or patients are not responding. Enrolment in clinical trials with newer pharmacological agents may be an option but AS and transplantation should be considered before systemic deterioration. Early referral for transplantation is crucial particularly for refractory cases [7]. A simplified therapeutic algorithm is suggested in Fig. 4.

\subsection{Non-PAH PH}

Patients will benefit from medical optimization of their primary disease, but significant PH may persist. Some patients actually present disproportionate $\mathrm{PH}$ not easily attributable to the underlying condition.

In left-heart disease prostanoids, with the exception of inhaled route, are usually contraindicated due to systemic vasodilation [118]. ERA trials have been interrupted prematurely due mainly to side-effects and absence of clinical benefit, even with reduced dose [119], but selected cases may benefit from short trials as a bridge to transplantation [120]. As
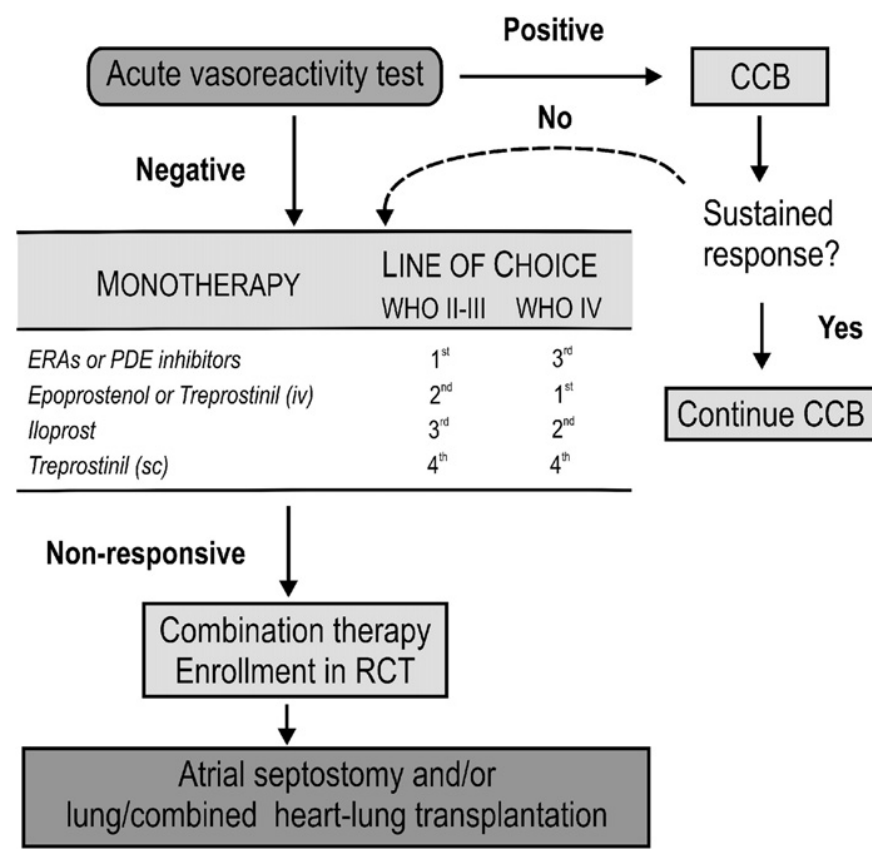

Fig. 4. Algorithm for pulmonary arterial hypertension (PAH) management. CCB, calcium channel blockers; WHO, World Health Organization; ERA, endothelin-1 receptor antagonists; PDEi, phosphodiesterase inhibitors; RCT, randomized clinical trials; iv, intravenous; $s c$, subcutaneous. *, among the ERAs only ambrisentan is approved for WHO class II patients. for PDEi short-term hemodynamic benefits, as well as long-term improvements have been documented [121].

Mild levels of PH are amenable to optimization of medical therapy in COPD. If PH is disproportionate, and other PH causes have been ruled out, many centres are routinely employing vasodilators despite $\mathrm{V}-\mathrm{Q}$ mismatch [122]. CTEPH is potentially curable with PEA [5]. Yet, many patients are not candidates so they remain anticoagulated and on diuretics. Many centres are promptly using new PAH drugs off-label if there is associated vasculopathy [123].

\subsection{Recent progresses and future targets in $\mathrm{PH}$}

Based upon the most recent experimental findings, clinical trials targeting altered metabolic and signalling pathways are warranted. DCA and Kv1.5 channel gene transfer have been successful in experimental studies [39], as well as trp channel inhibitors, growth factor receptor inhibitors and intracellular kinase inhibitors [3,124]. Inflammatory response modulation has also been a major research topic. After several animal studies demonstrating beneficial effects of statins [124], possibly due to pleiotropic effects, a human study disappointingly showed no long-lasting improvement [125]. Other immunomodulatory agents have been successful in animal experiments [50,126], but beneficial effects are mainly confined to CTD associated PAH [127]. We have also reported disturbances in endogenous endocrine and paracrine systems [128,129] that may be targeted. Another tempting possibility is the recruitment or infusion of EPC. The number and function of EPCs predicts prognosis, and most currently used drugs increase circulating EPC numbers [130]. Circulating EPCs home to sites of endothelial injury, promote revascularization and improve vascular homeostasis [131], endothelial dysfunction may be related to the lack of EPCs [130]. Finally, we must bear in mind that RV failure is the final and most severe complication of $\mathrm{PH}$. Agents such as levosimendan that vasodilate lung vessels but are also positive inotropes are predictably good therapeutic tools. Still, the clinical efficacy of these drugs has only just started to be evaluated $[132,133]$.

\section{Conflict of interest statement}

None declared.

\section{Acknowledgements}

The authors would like to thank Daniela Silva, José Pinto, Francisco Vasques-Nóvoa, Rui Cerqueira and Duarte Pinto for their contribution to the manuscript.

The authors of this manuscript have certified that they comply with the Principles of Ethical Publishing in the International Journal of Cardiology [152].

This work was supported by grants from Fundação para a Ciência e Tecnologia (PIC/IC/82943/2007, PTDC/SAU-MET/116119/2009 and PEst-C/SAU/UI0051/2011).

\section{References}

[1] Fishman AP. A century of pulmonary hemodynamics. Am J Respir Crit Care Med 2004;170:109-13.

[2] Chin KM, Rubin LJ. Pulmonary arterial hypertension. J Am Coll Cardiol 2008;51: 1527-38.

[3] Rabinovitch M. Molecular pathogenesis of pulmonary arterial hypertension. J Clin Invest 2008;118:2372-9.

[4] Humbert M. Update in pulmonary hypertension 2008. Am J Respir Crit Care Med 2009;179:650-6.

[5] Keogh AM, Mayer E, Benza RL, et al. Interventional and surgical modalities of treatment in pulmonary hypertension. J Am Coll Cardiol 2009;54:S67-77.

[6] Archer SL, Weir EK, Wilkins MR. Basic science of pulmonary arterial hypertension for clinicians: new concepts and experimental therapies. Circulation 2010;121: 2045-66.

[7] McLaughlin VV, Archer SL, Badesch DB, et al. ACCF/AHA 2009 expert consensus document on pulmonary hypertension a report of the American College of Cardiology Foundation Task Force on Expert Consensus Documents and the American Heart Association developed in collaboration with the American 
College of Chest Physicians; American Thoracic Society, Inc.; and the Pulmonary Hypertension Association. J Am Coll Cardiol 2009;53:1573-619.

[8] Kovacs G, Berghold A, Scheidl S, Olschewski H. Pulmonary arterial pressure during rest and exercise in healthy subjects: a systematic review. Eur Respir J 2009:34:888-94.

[9] Nef HM, Mollmann H, Hamm C, Grimminger F, Ghofrani HA. Pulmonary hypertension: updated classification and management of pulmonary hypertension. Heart 2010;96:552-9.

[10] Sitbon O, Humbert M, Jais X, et al. Long-term response to calcium channel blockers in idiopathic pulmonary arterial hypertension. Circulation 2005;111: 3105-11.

[11] Humbert M, Sitbon O, Chaouat A, et al. Pulmonary arterial hypertension in France: results from a national registry. Am J Respir Crit Care Med 2006;173: 1023-30.

[12] Peacock AJ, Murphy NF, McMurray JJ, Caballero L, Stewart S. An epidemiological study of pulmonary arterial hypertension. Eur Respir J 2007;30:104-9.

[13] Provencher S, Jais X, Yaici A, Sitbon O, Humbert M, Simonneau G. Clinical challenges in pulmonary hypertension: Roger S. Mitchell lecture. Chest 2005; $128: 622$ S-8S

[14] Fruchter O, Yigla M. Underlying aetiology of pulmonary hypertension in 191 patients: a single centre experience. Respirology 2008;13:825-31.

[15] Robbins IM, Newman JH, Johnson RF, et al. Association of the metabolic syndrome with pulmonary venous hypertension. Chest 2009;136:31-6.

[16] Butrous G, Ghofrani HA, Grimminger F. Pulmonary vascular disease in the developing world. Circulation 2008;118:1758-66.

[17] Leite-Moreira AF. Current perspectives in diastolic dysfunction and diastolic heart failure. Heart 2006;92:712-8.

[18] Shapiro BP, McGoon MD, Redfield MM. Unexplained pulmonary hypertension in elderly patients. Chest 2007;131:94-100.

[19] Ghio S, Gavazzi A, Campana C, et al. Independent and additive prognostic value of right ventricular systolic function and pulmonary artery pressure in patients with chronic heart failure. J Am Coll Cardiol 2001;37:183-8.

[20] Elliott CG, Barst RJ, Seeger W, et al. Worldwide physician education and training in pulmonary hypertension: pulmonary vascular disease: the global perspective. Chest 2010;137:85S-94S.

[21] Chaouat A, Bugnet AS, Kadaoui N, et al. Severe pulmonary hypertension and chronic obstructive pulmonary disease. Am J Respir Crit Care Med 2005;172: 189-94.

[22] Weitzenblum E, Hirth C, Ducolone A, Mirhom R, Rasaholinjanahary J, Ehrhart M. Prognostic value of pulmonary artery pressure in chronic obstructive pulmonary disease. Thorax 1981;36:752-8.

[23] Murray CJ, Lopez AD. Alternative projections of mortality and disability by cause 1990-2020: Global Burden of Disease Study. Lancet 1997;349:1498-504.

[24] MacNee W. Pathophysiology of cor pulmonale in chronic obstructive pulmonary disease. Part One. Am J Respir Crit Care Med 1994;150:833-52.

[25] Ghio S, Klersy C, Magrini G, et al. Prognostic relevance of the echocardiographic assessment of right ventricular function in patients with idiopathic pulmonary arterial hypertension. Int J Cardiol 2010;140:272-8.

[26] van Wolferen SA, Marcus JT, Boonstra A, et al. Prognostic value of right ventricular mass, volume, and function in idiopathic pulmonary arterial hypertension. Eur Heart J 2007;28:1250-7.

[27] Hoeper MM, Barbera JA, Channick RN, et al. Diagnosis, assessment, and treatment of non-pulmonary arterial hypertension pulmonary hypertension. J Am Coll Cardiol 2009;54:S85-96.

[28] Rodriguez-Roisin R, Krowka MJ, Herve P, Fallon MB. Pulmonary-hepatic vascular disorders (PHD). Eur Respir J 2004;24:861-80.

[29] Sun XG, Hansen JE, Oudiz RJ, Wasserman K. Pulmonary function in primary pulmonary hypertension. J Am Coll Cardiol 2003;41:1028-35.

[30] Miyamoto S, Nagaya N, Satoh T, et al. Clinical correlates and prognostic significance of six-minute walk test in patients with primary pulmonary hypertension. Comparison with cardiopulmonary exercise testing. Am J Respir Crit Care Med 2000;161:487-92.

[31] Pamidi S, Mehta S. Six-minute walk test in scleroderma-associated pulmonary arterial hypertension: are we counting what counts? J Rheumatol 2009;36: 216-8.

[32] Wensel R, Opitz CF, Anker SD, et al. Assessment of survival in patients with primary pulmonary hypertension: importance of cardiopulmonary exercise testing. Circulation 2002;106:319-24.

[33] Oudiz RJ, Barst RJ, Hansen JE, et al. Cardiopulmonary exercise testing and sixminute walk correlations in pulmonary arterial hypertension. Am J Cardio 2005;97:123-6

[34] Stauber RE, Olschewski H. Portopulmonary hypertension: short review. Eur J Gastroenterol Hepatol 2010;22:385-90.

[35] Robbins IM. Advancing therapy for pulmonary arterial hypertension: can animal models help? Am J Respir Crit Care Med 2004;169:5-6.

[36] Christman BW, McPherson CD, Newman JH, et al. An imbalance between the excretion of thromboxane and prostacyclin metabolites in pulmonary hypertension. N Engl J Med 1992;327:70-5.

[37] Sakao S, Tatsumi K, Voelkel NF. Endothelial cells and pulmonary arteria hypertension: apoptosis, proliferation, interaction and transdifferentiation. Respir Res 2009;10:95.

[38] Cowan KN, Jones PL, Rabinovitch M. Elastase and matrix metalloproteinase inhibitors induce regression, and tenascin- $C$ antisense prevents progression, of vascular disease. J Clin Invest 2000;105:21-34.

[39] Bonnet S, Michelakis ED, Porter C], et al. An abnormal mitochondrial-hypoxia inducible factor-1alpha-Kv channel pathway disrupts oxygen sensing and triggers pulmonary arterial hypertension in fawn hooded rats: similarities to human pulmonary arterial hypertension. Circulation 2006;113:2630-41.

[40] Archer SL, Gomberg-Maitland M, Maitland ML, Rich S, Garcia JG, Weir EK. Mitochondrial metabolism, redox signaling, and fusion: a mitochondria-ROSHIF-1alpha-Kv1.5 O2-sensing pathway at the intersection of pulmonary hypertension and cancer. Am J Physiol Heart Circ Physiol 2008;294:H570-8.

[41] Yang X, Long L, Southwood M, et al. Dysfunctional Smad signaling contributes to abnormal smooth muscle cell proliferation in familial pulmonary arterial hypertension. Circ Res 2005;96:1053-63.

[42] Morrell NW, Yang X, Upton PD, et al. Altered growth responses of pulmonary artery smooth muscle cells from patients with primary pulmonary hypertension to transforming growth factor-beta(1) and bone morphogenetic proteins. Circulation 2001;104:790-5.

[43] Newman JH, Trembath RC, Morse JA, et al. Genetic basis of pulmonary arterial hypertension: current understanding and future directions. J Am Coll Cardiol 2004;43:33S-9S

[44] MacLean MR, Dempsie Y. Serotonin and pulmonary hypertension-from bench to bedside? Curr Opin Pharmacol 2009;9:281-6.

[45] Landsberg JW, Yuan JX. Calcium and TRP channels in pulmonary vascular smooth muscle cell proliferation. News Physiol Sci 2004;19:44-50.

[46] Dorfmuller P, Perros F, Balabanian K, Humbert M. Inflammation in pulmonary arterial hypertension. Eur Respir J 2003;22:358-63.

[47] Humbert M, Monti G, Brenot F, et al. Increased interleukin-1 and interleukin-6 serum concentrations in severe primary pulmonary hypertension. Am J Respir Crit Care Med 1995;151:1628-31.

[48] Bonnet S, Rochefort G, Sutendra G, et al. The nuclear factor of activated T cells in pulmonary arterial hypertension can be therapeutically targeted. Proc Natl Acad Sci USA 2007; 104:11418-23.

[49] Steiner MK, Syrkina OL, Kolliputi N, Mark EJ, Hales CA, Waxman AB. Interleukin-6 overexpression induces pulmonary hypertension. Circ Res 2009;104:236-44

[50] Henriques-Coelho T, Oliveira SM, Moura RS, et al. Thymulin inhibits monocrotaline-induced pulmonary hypertension modulating interleukin-6 expression and suppressing p38 pathway. Endocrinology 2008;149:4367-73.

[51] Henriques-Coelho T, Brandao-Nogueira A, Moreira-Goncalves D, Correia-Pinto J, Leite-Moreira AF. Effects of TNF-alpha blockade in monocrotaline-induced pulmonary hypertension. Rev Port Cardiol 2008;27:341-8.

[52] von Haehling S, Doehner W, Anker SD. Nutrition, metabolism, and the complex pathophysiology of cachexia in chronic heart failure. Cardiovasc Res 2007;73: 298-309.

[53] Anker SD, Ponikowski P, Varney S, et al. Wasting as independent risk factor for mortality in chronic heart failure. Lancet 1997;349:1050-3.

[54] le Roux CW, Ghatei MA, Gibbs JS, Bloom SR. The putative satiety hormone PYY is raised in cardiac cachexia associated with primary pulmonary hypertension. Heart 2005;91:241-2.

[55] Bogaard HJ, Abe K, Vonk Noordegraaf A, Voelkel NF. The right ventricle under pressure: cellular and molecular mechanisms of right-heart failure in pulmonary hypertension. Chest 2009;135:794-804.

[56] Blaise G, Langleben D, Hubert B. Pulmonary arterial hypertension: pathophysiology and anesthetic approach. Anesthesiology 2003;99:1415-32.

[57] D'Alonzo GE, Barst RJ, Ayres SM, et al. Survival in patients with primary pulmonary hypertension. Results from a national prospective registry. Ann Intern Med 1991;115:343-9.

[58] Nagendran J, Archer SL, Soliman D, et al. Phosphodiesterase type 5 is highly expressed in the hypertrophied human right ventricle, and acute inhibition of phosphodiesterase type 5 improves contractility. Circulation 2007;116:238-48.

[59] Ritchie M, Waggoner AD, Davila-Roman VG, Barzilai B, Trulock EP, Eisenberg PR. Echocardiographic characterization of the improvement in right ventricular function in patients with severe pulmonary hypertension after single-lung transplantation. J Am Coll Cardiol 1993;22:1170-4.

[60] Miyauchi T, Yorikane R, Sakai S, et al. Contribution of endogenous endothelin-1 to the progression of cardiopulmonary alterations in rats with monocrotalineinduced pulmonary hypertension. Circ Res 1993;73:887-97.

[61] Lourenco AP, Roncon-Albuquerque Jr R, Bras-Silva C, et al. Myocardial dysfunction and neurohumoral activation without remodeling in left ventricle of monocrotaline-induced pulmonary hypertensive rats. Am J Physiol Heart Circ Physiol 2006;291:H1587-94.

[62] Bogaard HJ, Natarajan R, Henderson SC, et al. Chronic pulmonary artery pressure elevation is insufficient to explain right heart failure. Circulation 2009;120: 1951-60.

[63] van Wolferen SA, Marcus JT, Westerhof N, et al. Right coronary artery flow impairment in patients with pulmonary hypertension. Eur Heart J 2008;29: $120-7$.

[64] Piao L, Fang YH, Cadete VJ, et al. The inhibition of pyruvate dehydrogenase kinase improves impaired cardiac function and electrical remodeling in two models of right ventricular hypertrophy: resuscitating the hibernating right ventricle. J Mol Med 2009;88:47-60.

[65] Daicho T, Yagi T, Abe Y, et al. Possible involvement of mitochondrial energyproducing ability in the development of right ventricular failure in monocrotalineinduced pulmonary hypertensive rats. J Pharmacol Sci 2009;111:33-43.

[66] Hool LC. The L-type $\mathrm{Ca}(2+)$ channel as a potential mediator of pathology during alterations in cellular redox state. Heart Lung Circ 2009;18:3-10.

[67] Chang SM, Lin CC, Hsiao SH, et al. Pulmonary hypertension and left heart function: insights from tissue Doppler imaging and myocardial performance index. Echocardiography 2007;24:366-73.

[68] Dong SJ, Crawley AP, MacGregor JH, et al. Regional left ventricular systolic function in relation to the cavity geometry in patients with chronic right 
ventricular pressure overload. A three-dimensional tagged magnetic resonance imaging study. Circulation 1995;91:2359-70.

[69] Xie GY, Lin CS, Preston HM, et al. Assessment of left ventricular diastolic function after single lung transplantation in patients with severe pulmonary hypertension. Chest 1998:114:477-81.

[70] Pielsticker EJ, Martinez FJ, Rubenfire M. Lung and heart-lung transplant practice patterns in pulmonary hypertension centers. J Heart Lung Transplant 2001;20: 1297-304.

[71] Correia-Pinto J, Henriques-Coelho T, Roncon-Albuquerque Jr R, et al. Time course and mechanisms of left ventricular systolic and diastolic dysfunction in monocrotaline-induced pulmonary hypertension. Basic Res Cardiol 2009;104: 535-45.

[72] Wright JL, Levy RD, Churg A. Pulmonary hypertension in chronic obstructive pulmonary disease: current theories of pathogenesis and their implications for treatment. Thorax 2005;60:605-9.

[73] Agusti A. Systemic effects of chronic obstructive pulmonary disease: what we know and what we don't know (but should). Proc Am Thorac Soc 2007;4:522-5.

[74] Chaouat A, Savale L, Chouaid C, et al. Role for interleukin-6 in COPD-related pulmonary hypertension. Chest 2009;136:678-87.

[75] Barbera JA, Blanco I. Pulmonary hypertension in patients with chronic obstructive pulmonary disease: advances in pathophysiology and management. Drugs 2009;69:1153-71.

[76] Hoeper MM, Mayer E, Simonneau G, Rubin LJ. Chronic thromboembolic pulmonary hypertension. Circulation 2006;113:2011-20.

[77] Ribeiro A, Lindmarker P, Johnsson H, Juhlin-Dannfelt A, Jorfeldt L. Pulmonary embolism: one-year follow-up with echocardiography Doppler and five-year survival analysis. Circulation 1999;99:1325-30.

[78] Moser KM, Bloor CM. Pulmonary vascular lesions occurring in patients with chronic major vessel thromboembolic pulmonary hypertension. Chest 1993;103:685-92.

[79] Humbert M. Pulmonary arterial hypertension and chronic thromboembolic pulmonary hypertension: pathophysiology. Eur Respir Rev 2010;19:59-63.

[80] Drazner MH, Hamilton MA, Fonarow G, Creaser J, Flavell C, Stevenson LW. Relationship between right and left-sided filling pressures in 1000 patients with advanced heart failure. J Heart Lung Transplant 1999;18:1126-32.

[81] Moraes DL, Colucci WS, Givertz MM. Secondary pulmonary hypertension in chronic heart failure: the role of the endothelium in pathophysiology and management. Circulation 2000;102:1718-23.

[82] Huang W, Kingsbury MP, Turner MA, Donnelly JL, Flores NA, Sheridan DJ. Capillary filtration is reduced in lungs adapted to chronic heart failure: morphological and haemodynamic correlates. Cardiovasc Res 2001;49:207-17.

[83] Mehra MR, Kobashigawa J, Starling R, et al. Listing criteria for heart transplantation: International Society for Heart and Lung Transplantation guidelines for the care of cardiac transplant candidates-2006. J Heart Lung Transplant 2006;25:1024-42.

[84] McLaughlin VV, Presberg KW, Doyle RL, et al. Prognosis of pulmonary arterial hypertension: ACCP evidence-based clinical practice guidelines. Chest 2004;126: 78S-92S.

[85] McLaughlin VV, Suissa S. Prognosis of pulmonary arterial hypertension. The Power of Clinical Registries of Rare Diseases Circulation 2010;122:126-8.

[86] Humbert M, Sitbon O, Yaici A, et al. Survival in incident and prevalent cohorts of patients with pulmonary arterial hypertension. Eur Respir J 2010;36:549-55.

[87] Bishop JM, Cross KW. Physiological variables and mortality in patients with various categories of chronic respiratory disease. Bull Eur Physiopathol Respir 1984:20:495-500.

[88] Riedel M, Stanek V, Widimsky J, Prerovsky I. Longterm follow-up of patients with pulmonary thromboembolism. Late prognosis and evolution of hemodynamic and respiratory data. Chest 1982;81:151-8.

[89] Gavazzi A, Berzuini C, Campana C, et al. Value of right ventricular ejection fraction in predicting short-term prognosis of patients with severe chronic heart failure.J Heart Lung Transplant 1997;16:774-85.

[90] Weiss BM, Zemp L, Seifert B, Hess OM. Outcome of pulmonary vascular disease in pregnancy: a systematic overview from 1978 through 1996. J Am Coll Cardiol 1998;31:1650-7

[91] Rich S, Seidlitz M, Dodin E, et al. The short-term effects of digoxin in patients with right ventricular dysfunction from pulmonary hypertension. Chest 1998;114:787-92.

[92] Galie N, Manes A, Negro L, Palazzini M, Bacchi-Reggiani ML, Branzi A. A metaanalysis of randomized controlled trials in pulmonary arterial hypertension. Eur Heart J 2009;30:394-403.

[93] Rich S, Kaufmann E, Levy PS. The effect of high doses of calcium-channel blockers on survival in primary pulmonary hypertension. N Engl J Med 1992;327:76-81.

[94] Montani D, Savale L, Natali D, et al. Long-term response to calcium-channel blockers in non-idiopathic pulmonary arterial hypertension. Eur Heart J 2010;31: 1898-907.

[95] Nef HM, Mollmann H, Hamm C, Grimminger F, Ghofrani HA. Pulmonary hypertension: updated classification and management of pulmonary hypertension. Heart 2010;36:549-55.

[96] Barst RJ, Rubin LJ, Long WA, et al. A comparison of continuous intravenous epoprostenol (prostacyclin) with conventional therapy for primary pulmonary hypertension. The Primary Pulmonary Hypertension Study Group. N Engl J Med 1996;334:296-302.

[97] McLaughlin VV, Shillington A, Rich S. Survival in primary pulmonary hypertension: the impact of epoprostenol therapy. Circulation 2002;106:1477-82.

[98] Simonneau G, Barst RJ, Galie N, et al. Continuous subcutaneous infusion of treprostinil, a prostacyclin analogue, in patients with pulmonary arterial hypertension: a double-blind, randomized, placebo-controlled trial. Am J Respir Crit Care Med 2002;165:800-4.
[99] Olschewski H, Simonneau G, Galie N, et al. Inhaled iloprost for severe pulmonary hypertension. N Engl J Med 2002;347:322-9.

[100] McLaughlin VV, Benza RL, Rubin LJ, et al. Addition of inhaled treprostinil to oral therapy for pulmonary arterial hypertension: a randomized controlled clinical trial. J Am Coll Cardiol 2010;55:1915-22.

[101] Brunner F, Bras-Silva C, Cerdeira AS, Leite-Moreira AF. Cardiovascular endothelins: essential regulators of cardiovascular homeostasis. Pharmacol Ther 2006;111:508-31.

[102] Channick RN, Simonneau G, Sitbon O, et al. Effects of the dual endothelinreceptor antagonist bosentan in patients with pulmonary hypertension: a randomised placebo-controlled study. Lancet 2001;358:1119-23.

[103] Rubin LJ, Badesch DB, Barst RJ, et al. Bosentan therapy for pulmonary arterial hypertension. N Engl J Med 2002;346:896-903.

[104] Provencher S, Sitbon O, Humbert M, Cabrol S, Jais X, Simonneau G. Long-term outcome with first-line bosentan therapy in idiopathic pulmonary arterial hypertension. Eur Heart J 2006;27:589-95.

[105] Sitbon O, McLaughlin VV, Badesch DB, et al. Survival in patients with class III idiopathic pulmonary arterial hypertension treated with first line oral bosentan compared with an historical cohort of patients started on intravenous epoprostenol. Thorax 2005;60:1025-30.

[106] Galie N, Rubin L, Hoeper M, et al. Treatment of patients with mildly symptomatic pulmonary arterial hypertension with bosentan (EARLY study): a double-blind, randomised controlled trial. Lancet 2008;371:2093-100.

[107] Barst RJ, Rich S, Widlitz A, Horn EM, McLaughlin V, McFarlin J. Clinical efficacy of sitaxsentan, an endothelin-A receptor antagonist, in patients with pulmonary arterial hypertension: open-label pilot study. Chest 2002;121:1860-8.

[108] Oudiz RJ, Galie N, Olschewski H, et al. Long-term ambrisentan therapy for the treatment of pulmonary arterial hypertension. J Am Coll Cardiol 2009;54 1971-81.

[109] Germann P, Braschi A, Della Rocca G, et al. Inhaled nitric oxide therapy in adults: European expert recommendations. Intensive Care Med 2005;31:1029-41.

[110] Galie N, Ghofrani HA, Torbicki A, et al. Sildenafil citrate therapy for pulmonary arterial hypertension. N Engl J Med 2005;353:2148-57.

[111] Hoeper MM, Welte T. Sildenafil citrate therapy for pulmonary arterial hypertension. N Engl J Med 2006;354:1091-3 author reply -3.

[112] Archer SL, Michelakis ED. Phosphodiesterase type 5 inhibitors for pulmonary arterial hypertension. N Engl J Med 2009;361:1864-71.

[113] Humbert M, Barst RJ, Robbins IM, et al. Combination of bosentan with epoprostenol in pulmonary arterial hypertension: BREATHE-2. Eur Respir J 2004:24:353-9.

[114] McLaughlin VV, Oudiz RJ, Frost A, et al. Randomized study of adding inhaled iloprost to existing bosentan in pulmonary arterial hypertension. Am J Respir Crit Care Med 2006;174:1257-63.

[115] Simonneau G, Rubin LJ, Galie N, et al. Addition of sildenafil to long-term intravenous epoprostenol therapy in patients with pulmonary arterial hypertension: a randomized trial. Ann Intern Med 2008;149:521-30.

[116] Reichenberger F, Pepke-Zaba J, McNeil K, Parameshwar J, Shapiro LM. Atrial septostomy in the treatment of severe pulmonary arterial hypertension. Thorax 2003:58:797-800.

[117] Trulock EP, Christie JD, Edwards LB, et al. Registry of the International Society for Heart and Lung Transplantation: twenty-fourth official adult lung and heartlung transplantation report-2007. J Heart Lung Transplant 2007;26:782-95.

[118] Sablotzki A, Czeslick E, Gruenig E, et al. First experiences with the stable prostacyclin analog iloprost in the evaluation of heart transplant candidates with increased pulmonary vascular resistance. J Thorac Cardiovasc Surg 2003;125: $960-2$.

[119] Teerlink JR. Recent heart failure trials of neurohormonal modulation (OVERTURE and ENABLE): approaching the asymptote of efficacy? J Card Fail 2002;8:124-7.

[120] Perez-Villa F, Cuppoletti A, Rossel V, Vallejos I, Roig E. Initial experience with bosentan therapy in patients considered ineligible for heart transplantation because of severe pulmonary hypertension. Clin Transplant 2006;20:239-44.

[121] Lewis GD, Shah R, Shahzad K, et al. Sildenafil improves exercise capacity and quality of life in patients with systolic heart failure and secondary pulmonary hypertension. Circulation 2007:116:1555-62.

[122] Maloney JP. Advances in the treatment of secondary pulmonary hypertension. Curr Opin Pulm Med 2003;9:139-43.

[123] Jais X, D'Armini AM, Jansa P, et al. Bosentan for treatment of inoperable chronic thromboembolic pulmonary hypertension: BENEFiT (Bosentan Effects in iNopErable Forms of chronIc Thromboembolic pulmonary hypertension), a randomized, placebo-controlled trial. J Am Coll Cardiol 2008;52:2127-34.

[124] Rhodes CJ, Davidson A, Gibbs JS, Wharton J, Wilkins MR. Therapeutic targets in pulmonary arterial hypertension. Pharmacol Ther 2009;121:69-88.

[125] Wilkins MR, Ali O, Bradlow W, et al. Simvastatin as a treatment for pulmonary hypertension trial. Am J Respir Crit Care Med 2010;181:1106-13.

[126] Suzuki C, Takahashi M, Morimoto H, et al. Mycophenolate mofetil attenuates pulmonary arterial hypertension in rats. Biochem Biophys Res Commun 2006;349:781-8.

[127] Sanchez O, Sitbon O, Jais X, Simonneau G, Humbert M. Immunosuppressive therapy in connective tissue diseases-associated pulmonary arterial hypertension. Chest 2006;130:182-9.

[128] Henriques-Coelho T, Correia-Pinto J, Roncon-Albuquerque Jr R, et al. Endogenous production of ghrelin and beneficial effects of its exogenous administration in monocrotaline-induced pulmonary hypertension. Am J Physiol Heart Circ Physiol 2004;287:H2885-90.

[129] Falcao-Pires I, Goncalves N, Henriques-Coelho T, Moreira-Goncalves D, RonconAlbuquerque Jr R, Leite-Moreira AF. Apelin decreases myocardial injury and 
improves right ventricular function in monocrotaline-induced pulmonary hypertension. Am J Physiol Heart Circ Physiol 2009;296:H2007-14.

[130] Diller GP, van Eijl S, Okonko DO, et al. Circulating endothelial progenitor cells in patients with Eisenmenger syndrome and idiopathic pulmonary arterial hypertension. Circulation 2008;117:3020-30.

[131] Povsic TJ, Goldschmidt-Clermont PJ. Endothelial progenitor cells: markers of vascular reparative capacity. Ther Adv Cardiovasc Dis 2008;2:199-213.

[132] Cavusoglu Y, Beyaztas A, Birdane A, Ata N. Levosimendan is not effective in reducing pulmonary pressures in patients with idiopathic pulmonary arterial hypertension: report of two cases. J Cardiovasc Med (Hagerstown) 2009;10:503-7.

[133] Morais RJ. Levosimendan in severe right ventricular failure following mitral valve replacement. J Cardiothorac Vasc Anesth 2006;20:82-4

[134] ATS statement: guidelines for the six-minute walk test. Am J Respir Crit Care Med 2002; $166: 111-7$.

[135] Rasekaba T, Lee AL, Naughton MT, Williams TJ, Holland AE. The six-minute walk test: a useful metric for the cardiopulmonary patient. Intern Med J 2009;39:495-501.

[136] Borg GA. Psychophysical bases of perceived exertion. Med Sci Sports Exerc 1982:14:377-81.

[137] Galie N, Humbert M, Vachiery JL, et al. Effects of beraprost sodium, an oral prostacyclin analogue, in patients with pulmonary arterial hypertension: a randomized, doubleblind, placebo-controlled trial. J Am Coll Cardiol 2002;39:1496-502.

[138] Barst RJ, McGoon M, McLaughlin V, et al. Beraprost therapy for pulmonary arterial hypertension. J Am Coll Cardiol 2003;41:2119-25.

[139] McLaughlin VV, Sitbon O, Badesch DB, et al. Survival with first-line bosentan in patients with primary pulmonary hypertension. Eur Respir J 2005;25:244-9.

[140] Galie N, Beghetti M, Gatzoulis MA, et al. Bosentan therapy in patients with Eisenmenger syndrome: a multicenter, double-blind, randomized, placebocontrolled study. Circulation 2006; 114:48-54.

[141] Galie N, Badesch D, Oudiz R, et al. Ambrisentan therapy for pulmonary arteria hypertension. J Am Coll Cardiol 2005;46:529-35.
[142] Galie N, Olschewski H, Oudiz RJ, et al. Ambrisentan for the treatment of pulmonary arterial hypertension: results of the ambrisentan in pulmonary arterial hypertension, randomized, double-blind, placebo-controlled, multicenter, efficacy (ARIES) study 1 and 2. Circulation 2008;117:3010-9.

[143] Barst RJ, Langleben D, Frost A, et al. Sitaxsentan therapy for pulmonary arterial hypertension. Am J Respir Crit Care Med 2004;169:441-7.

[144] Barst RJ, Langleben D, Badesch D, et al. Treatment of pulmonary arterial hypertension with the selective endothelin-A receptor antagonist sitaxsentan. J Am Coll Cardiol 2006;47:2049-56.

[145] Galie N, Brundage BH, Ghofrani HA, et al. Tadalafil therapy for pulmonary arterial hypertension. Circulation 2009;119:2894-903.

[146] Archer SL, Weir EK, Wilkins MR. Basic science of pulmonary arterial hypertension for clinicians: new concepts and experimental therapies. Circulation 2010;121: 2045-66.

[147] Nagaya N, Uematsu M, Kojima M, et al. Chronic administration of ghrelin improves left ventricular dysfunction and attenuates development of cardiac cachexia in rats with heart failure. Circulation 2001;104:1430-5.

[148] Yang J, Li X, Al-Lamki RS, et al. Smad-dependent and smad-independent induction of id1 by prostacyclin analogues inhibits proliferation of pulmonary artery smooth muscle cells in vitro and in vivo. Circ Res 2010;107:252-62.

[149] West J. Cross talk between Smad, MAPK, and actin in the etiology of pulmonary arterial hypertension. Adv Exp Med Biol 2010;661:265-78.

[150] Shi Y, Massague J. Mechanisms of TGF-beta signaling from cell membrane to the nucleus. Cell 2003;113:685-700.

[151] Yang J, Davies RJ, Southwood M, et al. Mutations in bone morphogenetic protein type II receptor cause dysregulation of Id gene expression in pulmonary artery smooth muscle cells: implications for familial pulmonary arterial hypertension. Circ Res 2008;102:1212-21.

[152] Shewan LG, Coats AJ. Ethics in the authorship and publishing of scientific articles. Int J Cardiol 2010;144:1-2. 